\title{
/NE/ZAKONITI DOKAZI U KAZNENOM POSTUPKU (POSEBAN OSVRT NA MJERE TAJNOG SNIMANJA TELEFONSKIH RAZGOVORA I TREĆEGA U TIM RADNJAMA)
}

Dr. sc. Jakob Nakić, znanstveni suradnik, Zamjenik županijske državne odvjetnice u Rijeci Marko Rogić, mag.iur., odvjetnik iz Rijeke

\author{
UDK: 343.14 \\ Ur.: 13. siječnja 2016. \\ Pr.: 10. ožujka 2016. \\ Pregledni znanstveni rad
}

\begin{abstract}
Sažetak
Rad se bavi pitanjima nezakonitih dokaza u okvirima hrvatskoga kaznenog postu"povnog prava dajući kratki pregled temeljnih načela $i$ polazišta definiranih primjenjivim pravnim izvorištima, odnosno nacionalnim postupovnim zakonodavstvom, Ustavom RH i Europskom konvencijom. Konkretnije, smisao rada jest analiza valjanosti uporabe (iskoristivosti) sadržaja prikupljenih mjerama tajnog snimanja telefonskih razgovora prema trećima osobama, odnosno osobama prema kojima takve mjere nisu bile inicijalno određene, a sve u smislu odredbe članka 8. Europske konvencije i opravdanih očekivanja u zaštiti temeljnih prava na privatnost i općenje. Ova pitanja analizirana su komparacijom nacionalnog sudovanja i temeljnog standarda zaštite prava fundiranog na presudama ESLJP-a, sa zaključkom kako su određene promjene u nacionalnom zakonodavstvu (Zakon o kaznenom postupku) nužne, želi li se ispuniti postavljene standarde.
\end{abstract}

Ključne riječi: nezakoniti dokazi, plod otrovne voćke, mjere tajnog snimanja, telefonski razgovori, Zakon o kaznenom postupku, Europski sud za ljudska prava, Ustavni sud, Vrhovni sud.

\section{1. $U V O D$}

Pojam nezakonitih dokaza jedan je od središnjih pojmova suvremenog “dokaznog” prava. Kompleksnost tog problema spada u najteža pitanja kaznenog procesnog prava. Razlog tome je u dvojakom cilju i svrsi kaznenog postupka. Suvremeni kazneni postupak nastoji održati ravnotežu između dviju osnovnih, a suprotstavljenih, tendencija - naime, tendencije funkcionalnosti kažnjavanja, s jedne, i zaštite prava građana, s druge strane. Te se dvije tendencije najdramatičnije 
sukobljavaju u institutu nezakonitih dokaza. Rješavanje pitanja nezakonitih dokaza u temeljima je ostvarenja svrhe djelovanja kaznenog pravosuđa kao onoga koji primjenjuje kazneno procesno pravo, a još i više dolazi do izražaja prelaskom hrvatskoga kaznenog procesnog sustava u "ligu akuzatornosti" prima facie.

Pojam nezakonitog dokaza određuje se funkcionalno, i to na dva načina:

- prvi, s obzirom na kvalitetu i podrijetlo njegove dokazne nekredibilnosti, koja se manifestira u opreci tog dokaza odgovarajućim pravilima koja se odnose na način na koji je pribavljen;

- drugi, s obzirom na suprotnost u odnosu na pravila sadržana u nekoliko alternativno navedenih izvora prava, tako da dokaz sam po sebi ili prema načinu pribavljanja, može biti u suprotnosti s odredbama:

1) Ustava Republike Hrvatske,

2) međunarodnog ugovora koji je ratificirala Republika Hrvatska, $i$

3) Zakona o kaznenom postupku, ali samo bitnim povredama navedenoga zakona.

Prema tome, u biti, nezakonit dokaz je zabranjen bez obzira na njegovu pouzdanost, istinitost i vjerodostojnost pa se u ocjenu spoznajne vrijednosti dokaza može ući tek po testiranju dopustivosti modusa (pravila postupanja) pribavljanja određenog dokaza. ${ }^{1}$

Svi europski zakoni kaznenog procesnog prava ${ }^{2}$ propisuju zabranu temeljenja sudskih pravorijeka na dokazima pribavljenim na nezakoniti način.

Kazneno procesno pravo dokazima pribavljenim kršenjem osnovnih prava i sloboda građana oduzima svako pravno značenje. Prava na formalnu i materijalnu obranu predviđena su u članku 14. Međunarodnog pakta o građanskim i političkim pravima $^{3}$ te u članku 6. Europske konvencije za zaštitu ljudskih prava i temeljnih sloboda. ${ }^{4}$ Pravo na dostojanstvo, ugled i čast, kao i pravo na nepovredivost osobnog i obiteljskog života predviđaju se u članku 17. Međunarodnog pakta o građanskim i političkim pravima te članku 7. EKZLJP-a.

1 Pavišić, Berislav, Komentar zakona o kaznenom postupku, Dušević \& Kršovnik, Rijeka, 2011., str. 91.

2 Grupa autora, E.U. NETWORK OF INDEPENDENT EXPERTS ON FUNDAMENTAL RIGHTS (CFR-CDF Opinion on the status of illegally obtained evidence in criminal procedures in the Member States of the European Union, vidi na: http://www.europa. eu.int/comm/justice_home/cfr_cdf/index_en.htm, Osborn, Debra, Suppressing the Truth: Judicial Exclusion of Illegally Obtained Evidence in the United States, Canada, England and Australia, vidi na: http://www.cridho.cpdr.ucl.ac.be/documents/Avis.CFR.../CFR-CDF. opinion3-2003.pdf

3 Narodne novine, Međunarodni ugovori, br. 127/93, 11/95

4 Konvencija s protokolima objavljen je u Narodnim novinama, Međunarodni ugovori, br. 18/97, 6/99, 9/99, 14/02, 13/03, 9/05, 1/06, $2 / 10$ (dalje: EKZLJP). 
Nezakoniti dokazi pribavljeni povredama ljudskih prava i sloboda propisanih Ustavom RH i međunarodnim ugovorima koje je ratificirala Republika Hrvatska su:

- dokazi koji su pribavljeni povredom prava na obranu (članak 6. stavak 3. EKZLJP),

- povredom prava na dostojanstvo, ugled i čast (članak 3. EKZLJP),

- povredom prava na nepovredivost osobnog i obiteljskog života (članak 8. EKZLJP).

Koje će dokaze sud, in concreto, izvesti tijekom kaznenog postupka, kao niti njihovu dokaznu snagu ne određuje zakon. Naime, sud nije vezan formalnim dokaznim pravilima u istom pravcu pa tijekom postupka može sve činjenice utvrđivati bilo kojom vrstom dokaza koju smatra potrebnom i prikladnom da stekne uvjerenje o njezinom (ne)postojanju.

$\mathrm{S}$ obzirom na prosječnu duljinu trajanja kaznenih postupaka u Republici Hrvatskoj, još će se neko vrijeme (mjereno u godinama), u judikaturi zadržati dihtomija primjene dvaju kazneno - postupovnih uređenja, odnosno mješovitog sustava prema tradicionalnom ZKP/97 ${ }^{5}$ i akuzatornog sustava prema "novom" ZKP/08. Naime, ZKP/08 zaživio je u općoj primjeni dana 1. rujna 2011. (prethodno samo u predmetima iz nadležnosti USKOK-a, od dana 1. srpnja 2009.), međutim, u postupcima koji su pokrenuti do dana 1. rujna 2011. i dalje se u cijelosti primjenjuju odredbe ZKP/97. Iz istog će razloga predmet analize ovog rada obuhvaćati uređenje materije nezakonitih dokaza shodno pozitivnom uređenju ZKP/97, ZKP/08 i ZKP/14.

5 Izrazom ZPK/97 obuhvaćen je ZKP (Narodne novine, br. 62/03, 115/06 - članci su numerirani prema tekstu Zakona o kaznenom postupku objavljenom u Narodnim novinama, br. 110/97, 27/98, 58/99, 112/99, 58/02 i 143/02, dok se u zagradama, počevši sa člankom 90.a, navodi numeracija iz pročišćenog teksta objavljenog u Narodnim novinama, br. 62/03. Izrazom ZKP/08 obuhvaćen je ZKP (Narodne novine, br. 152/08, 76/09, 80/11, 91/12 - Odluka i Rješenje USRH i 143/12). Izrazom ZKP/13 obuhvaćen je ZKP (Narodne novine, br. 153/13). Izrazom ZKP/14 obuhvaćen je ZKP/08 uz Zakon o izmjenama i dopunama ZKP (Narodne novine, br. 152/14). 
Odredbom članka 9. ZKP/97, članka 10. ZKP/08 i ZKP/14 propisano je:

\begin{tabular}{|c|c|c|}
\hline $\begin{array}{l}\text { ZKP/976 } \\
\text { članak } 9 .\end{array}$ & $\begin{array}{c}\mathrm{ZKP} / 08^{7} \\
\text { članak } 10 .\end{array}$ & $\begin{array}{c}\mathrm{ZKP} / 14^{8} \\
\text { članak } 10 .\end{array}$ \\
\hline $\begin{array}{l}\text { (1) Sudske se odluke } \\
\text { ne mogu utemeljiti na } \\
\text { dokazima pribavljenim na } \\
\text { nezakonit način (nezakoniti } \\
\text { dokazi). } \\
\text { (2) Nezakoniti jesu oni } \\
\text { dokazi koji su pribavljeni } \\
\text { kršenjem Ustavom, } \\
\text { zakonom ili međunarodnim } \\
\text { pravom zajamčenih } \\
\text { prava obrane, prava na } \\
\text { dostojanstvo, ugled i čast } \\
\text { te prava na nepovredivost } \\
\text { osobnog i obiteljskog } \\
\text { života kao i oni dokazi koji } \\
\text { su pribavljeni povredom } \\
\text { odredaba kaznenog } \\
\text { postupka i koji su izričito } \\
\text { predviđeni ovim Zakonom } \\
\text { te drugi dokazi za koje se } \\
\text { iz njih saznalo." }\end{array}$ & $\begin{array}{l}\text { (1) Sudske se odluke ne } \\
\text { mogu temeljiti na dokazima } \\
\text { pribavljenim na nezakonit } \\
\text { način (nezakoniti dokazi). } \\
\text { (2) Nezakoniti su dokazi: } \\
\text { 1) koji su pribavljeni } \\
\text { kršenjem Ustavom, zakonom } \\
\text { ili međunarodnim pravom } \\
\text { propisane zabrane mučenja, } \\
\text { okrutnog ili nečovječnog } \\
\text { postupanja te zabrane povrede } \\
\text { prava na dostojanstvo, } \\
\text { 2) koji su pribavljeni } \\
\text { povredom Ustavom, zakonom } \\
\text { ili međunarodnim pravom } \\
\text { zajamčenih prava obrane, } \\
\text { prava na dostojanstvo, ugled } i \\
\text { čast, te prava na nepovredivost } \\
\text { osobnog i obiteljskog života, } \\
\text { 3) koji su pribavljeni povredom } \\
\text { odredaba kaznenog postupka i } \\
\text { koji su izričito predviđeni ovim } \\
\text { Zakonom, } \\
\text { 4) za koje se saznalo iz } \\
\text { nezakonitih dokaza. } \\
\text { (3) Ne smatraju se nezakonitim } \\
\text { dokazi pribavljeni povredom } \\
\text { prava i sloboda iz stavka } 2 . \\
\text { točke } 2 . \text { ovog članka: } \\
\text { 1) radnjom za koju je prema } \\
\text { kaznenom zakonu isključena } \\
\text { protupravnost, } \\
\text { 2) u postupku za teške oblike } \\
\text { kaznenih djela za koja se } \\
\text { provodi redoviti postupak, } \\
\text { kod kojih je povreda prava, } \\
\text { s obzirom na jakost i narav, } \\
\text { bitno manja u odnosu na težinu } \\
\text { kaznenog djela. } \\
\text { (4) Sudska odluka ne može se } \\
\text { temeljiti isključivo na dokazu } \\
\text { iz stavka 3. točke 2. ovog } \\
\text { članka." }\end{array}$ & $\begin{array}{l}\text { (1) Sudske se odluke ne } \\
\text { mogu temeljiti na dokazima } \\
\text { pribavljenim na nezakonit } \\
\text { način (nezakoniti dokazi). } \\
\text { (2) Nezakoniti su dokazi: } \\
\text { 1) koji su pribavljeni } \\
\text { kršenjem Ustavom, } \\
\text { zakonom ili medunarodnim } \\
\text { pravom propisane zabrane } \\
\text { mučenja, nečovječnog ili } \\
\text { ponižavajućeg postupanja, } \\
\text { 2) koji su pribavljeni } \\
\text { povredom Ustavom, zakonom } \\
\text { ili međunarodnim pravom } \\
\text { zajamčenih prava obrane, } \\
\text { prava na ugled i čast, te } \\
\text { prava na nepovredivost } \\
\text { osobnog i obiteljskog života, } \\
\text { osim u slučaju iz stavka } 3 . \\
\text { ovog članka, } \\
\text { 3) koji su pribavljeni } \\
\text { povredom odredaba } \\
\text { kaznenog postupka i koji } \\
\text { su izričito predviđeni ovim } \\
\text { Zakonom, } \\
\text { 4) za koje se saznalo iz } \\
\text { nezakonitih dokaza. } \\
\text { (3) Ne smatraju se } \\
\text { nezakonitima dokazi } \\
\text { pribavljeni povredom prava } \\
\text { i sloboda iz stavka } 2 . \text { točke } \\
\text { 2. ovog članka u postupku za } \\
\text { teške oblike kaznenih djela iz } \\
\text { nadležnosti županijskog suda, } \\
\text { kod kojih interes kaznenog } \\
\text { progona i kažnjavanja } \\
\text { počinitelja preteže nad } \\
\text { povredom prava. } \\
\text { (4) Sudska odluka ne može se } \\
\text { temeljiti isključivo na dokazu } \\
\text { iz stavka 3. ovog članka." }\end{array}$ \\
\hline
\end{tabular}

6 Ova definicija ukazuje nam da ZKP/97 ne nadovezuje na svaku pogrešku pri sakupljanju i izvođenju dokaza sankciju neuporabljivosti, već to čini samo onda kada se radi o dokazima 
Usporedbom uređenja materije nezakonitih dokaza u dva postupovna zakona, razvidno je kako $\mathrm{ZKP} / 08$, odredbom članka 10. stavak 3. točka 2., inaugurira načelo razmjernosti u ocjeni temeljnih zadaća kaznenog sudovanja spomenutih $\mathrm{u}$ uvodnom dijelu predmetnog rada, odnosno dopušta upliv formalno i supstancijalno nezakonitih dokaza nastalih povredama širokog raspona temeljnih prava i sloboda (obrana, dostojanstvo, ugled i čast, nepovredivost osobnog i obiteljskog života) u kaznenim postupcima za najteža kaznena djela za koja se provodi redoviti postupak. Koliko god je, s pozicije represivnog i preventivnog momenta kaznenog postupka, takvo uređenje razumljivo, toliko s aspekta temeljnih ljudskih prava, zajamčenih ustavnim i međunarodno-konvencijskim uređenjem, trpi ozbiljnu kritiku. Odredbom stavka 4. istog članka uvodi se, prema našem mišljenju, slabašni korektiv u smislu da se sudska odluka ne može temeljiti isključivo na takvom dokazu. No, koji će to drugi dokazi i kakve kvalitete biti dostatni da podupru takav nezakoniti dokaz u svojem spoznajnom značaju, stvar je razvoja i stavova sudske prakse (dakle, questio facti), koja, unatoč načelnoj neovisnosti, ipak nije potpuno imuna društvene kontekstualizacije u kojoj se događa, a napose kod najtežih oblika kriminaliteta za koje je sporna iznimka rezervirana.

kod čijeg se prikupljanja i izvođenja, neovisno o pitanju njihove pouzdanosti javljaju kršenja određenih procesnih formi namijenjenih zaštiti određenih osobnih prava i sloboda građana ili okrivljenikovih prava obrane u kaznenom postupku.

Nezakoniti dokazi iz članka 9. ZKP/97 mogu se podijeliti na tri skupine.

U prvoj su dokazi pribavljeni povredom određenih temeljnih prava i sloboda građana (pravo na ugled i čast, pravo na dostojanstvo, pravo na formalnu i materijalnu obranu, pravo na nepovredivost osobnog i obiteljskog života).

U drugoj skupini su dokazi koji su izričito u zakonu predviđeni kao neupotrebljivi pri donošenju sudske odluke u kaznenom postupku. ZKP/97 predviđa pet kategorija dokaza:

1. čl. 182. st. 6. ZKP/97 i čl. 42. st. 8. Zakona o uredu za suzbijanje korupcije i organiziranog kriminala (Narodne novine, br. 88/01, 12/02, 33/05, 48/05 i 76/07, 76/09, 116/10, 145/10, 57/11, 136/12, dalje: ZUSKOK),

2. čl. 232. ZKP/97,

3. čl. 237. st. 9 . ZKP/97,

4. čl. 235. ZKP/97 i čl. 34. t. 2. ZUSKOK,

5. čl. 250. st. 1. ZKP/97.

U trećoj skupini su dokazi za koje se saznalo pomoću nezakonitih dokaza, tzv. doktrina „ploda otrovne voćke“.

7 Valja imati na umu i odluku Ustavnog suda RH, U-I-448/2009, od 19. srpnja 2012., Narodne novine, br. 91/12 i na: http://www.usud.hr. Naime, tom je odlukom točkom I. pokrenut postupak za ocjenu suglasnosti s Ustavom Zakona o kaznenom postupku (Narodne novine, br. 152/08, 76/09, 80/11) te se, među inim, ukida i članak 10. stavak 3. u dijelu koji se odnosi na pravo na dostojanstvo iz članka 10. stavka 2. točka 2. ZKP-a.

8 Izmjena ovoga članka najvećim dijelom predstavlja nomotehničku izmjenu. Tako je primjerice u stavku 2. točka 1. ispušten izričaj "okrutno postupanje". To je prvenstveno učinjeno radi toga jer taj izričaj nije poznat niti u međunarodnim propisima ali niti u Ustavu RH. Stavak 3. sada nešto drukčije određuje iznimku kada neki dokaz, premda pribavljen povredom prava obrane, prava na ugled i čast i nepovredivosti osobnog i obiteljskog života, ipak nije nezakoniti dokaz. Da bi postojala narečena iznimka moraju biti kumulativno ispunjene ove pretpostavke: a) da se radi o postupku za teške oblike kaznenih djela iz nadležnosti županijskog suda i b) da se sudska odluka ne može zasnivati isključivo na takvom dokazu. 


\section{2. (NE)ZAKONITI DOKAZI}

Temeljna ustavna odredba koja se tiče zabrane uporabe nezakonitih dokaza u sudskim postupcima uopće, a onda i u kaznenom postupku, propisana je na sljedeći način u članku 29. stavak 4. Ustava Republike Hrvatske:"

"Dokazi pribavljeni na nezakonit način ne mogu se uporabiti u sudskom postupku."

$\mathrm{Na}$ ovom mjestu valja skrenuti pažnju na činjenicu kako tekst citirane odredbe definira materiju nezakonitih dokaza znatno šire od zahvata odredbi članka 9. ZKP/97 i članka 10. ZKP/08, s obzirom na to da ista apsolutno isključuje mogućnost uporabe nezakonitih dokaza u sudskim postupcima, dok citirane odredbe postupovnog zakonodavstva zabranjuju utemeljenje sudske odluke na određenom nezakonitom dokazu.

Bitna svojstva ustavno-pravne zabrane uporabe nezakonitih dokaza, mogu se sumirati na sljedeće postavke:

- zabrana vrijedi u svim postupcima, dakle, glavnom i sporednima (prethodna pitanja, troškovi postupka, oduzimanje imovinske koristi i sl.),

- zabrana vrijedi za sve oblike kaznenog postupka,

- zabrana se odnosi na sve etape kaznenog postupka,

- zabrana se odnosi na dokaze koji idu u prilog i na štetu okrivljenika. ${ }^{10}$

Člankom 35. Ustava RH propisano je:

"Svakom se jamči štovanje i pravna zaštita njegova osobnog i obiteljskog života, dostojanstva, ugleda i časti."

Valja ukazati i na odredbu članka 36. Ustava RH:

"Sloboda i tajnost dopisivanja $i$ svih drugih oblika općenja zajamčena je $i$ nepovrediva.

Samo se zakonom mogu propisati ograničenja nužna za zaštitu sigurnosti države ili provedbu kaznenog postupka."

9 Narodne novine, br. 56/90, 135/97, 8/98 - pročišćeni tekst, 113/00, 124/00 - pročišćeni tekst, 28/01, 41/01 - pročišćeni tekst, 55/01 - ispravak, 76/10, 85/10 - pročišćeni tekst, dalje: Ustav RH. Vidi i Izvješće o ustavnopravno neprihvatljivim učincima pročišćenih tekstova Ustava Republike Hrvatske, ustavnih zakona, zakona, drugih propisa i općih akata, Ustavnog suda Republike Hrvatske, U-X-1435/11, od 23. ožujka 2011. godine, vidi na: http://www.usud.hr

10 Doduše, pojedini autori (primjerice Pavišić) smatraju kako ista zabrana ne bi smjela ići protiv načela in favorem defensionis, tj. da je prvotna zadaća iste spriječiti postupke tijela državne vlasti kojima se krše temeljna prava, dok se iste ne smije pretvoriti u suprotnost, odnosno da bi bila protivna interesima okrivljenika. 
Odredbe članka 180. (190.) ZKP/97, članka 332. ZKP/08 i članak 332/14 određuju:

\begin{tabular}{|c|c|c|}
\hline ZKP/97 & ZKP/08 & $\mathrm{ZKP} / 14^{11}$ \\
\hline $\begin{array}{l}\text { 4. Posebni izvidi kaznenih } \\
\text { djela privremenim } \\
\text { ograničenjem ustavnih prava } \\
\quad \text { i sloboda } \\
\quad \text { Članak } 180 \text {. (190.) } \\
\text { (1) Ako se izvidi kaznenih } \\
\text { djela ne bi mogli provesti } \\
\text { na drugi način ili bi bili } \\
\text { skopčani s nerazmjernim } \\
\text { teškoćama, na zahtjev } \\
\text { državnog odvjetnika istražni } \\
\text { sudac može protiv osobe za } \\
\text { koju postoje osnove sumnje } \\
\text { da je sama počinila ili } \\
\text { zajedno s drugim osobama } \\
\text { sudjelovala u kaznenom } \\
\text { djelu iz članka 192. ovoga } \\
\text { Zakona odrediti mjere kojima } \\
\text { se privremeno ograničavaju } \\
\text { određena ustavna prava } \\
\text { građđana, i to: } \\
\text { 1) nadzor i tehničko snimanje } \\
\text { telefonskih razgovora, } \\
\text { odnosno sredstava za } \\
\text { tehničko komuniciranje na } \\
\text { daljinu, } \\
\text { 2) ulazak u prostorije } \\
\text { radi provođenja nadzora i } \\
\text { tehničko snimanje prostorija, } \\
\text { 3) tajno praćenje i tehničko } \\
\text { snimanje osoba i predmeta, } \\
\text { 4) uporabu prikrivenih } \\
\text { istražitelja i pouzdanika, } \\
\text { 5) simulirani otkup predmeta } \\
\text { te simulirano davanje } \\
\text { potkupnine i simulirano } \\
\text { primanje potkupnine, } \\
\text { 6) nadzirani prijevoz i } \\
\text { isporuku predmeta kaznenog } \\
\text { djela. } \\
\text { (2) Mjere iz točke } 1 \text {. stavka } \\
\text { 1. ovoga članka mogu se } \\
\text { odrediti i prema osobama za } \\
\text { koje postoje osnove sumnje } \\
\text { da počinitelju ili od }\end{array}$ & 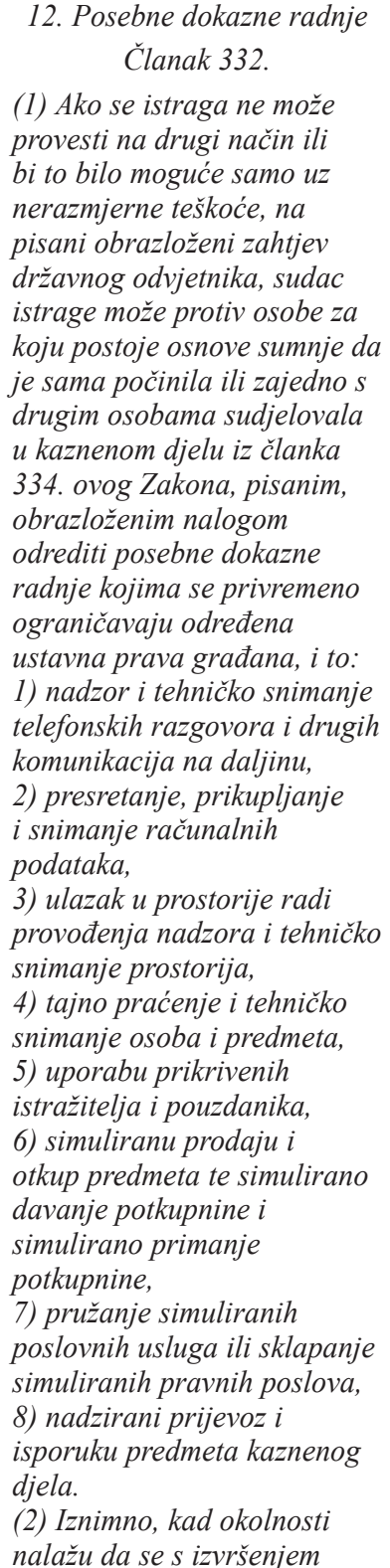 & $\begin{array}{l}\text { 12. Posebne dokazne radnje } \\
\quad \text { Članak } 332 . \\
\text { (1) Ako se izvidi kaznenih djela } \\
\text { ne bi mogli provesti na drugi } \\
\text { način ili bi to bilo moguće } \\
\text { samo uz nerazmjerne teškoće, } \\
\text { na pisani obrazloženi zahtjev } \\
\text { državnog odvjetnika, sudac } \\
\text { istrage može protiv osobe za } \\
\text { koju postoje osnove sumnje da } \\
\text { je sama počinila ili zajedno s } \\
\text { drugim osobama sudjelovala } \\
\text { u kaznenom djelu iz članka } \\
\text { 334. ovog Zakona, pisanim, } \\
\text { obrazloženim nalogom } \\
\text { odrediti posebne dokazne } \\
\text { radnje kojima se privremeno } \\
\text { ograničavaju određena } \\
\text { ustavna prava građana, i to: } \\
\text { 1) nadzor i tehničko snimanje } \\
\text { telefonskih razgovora i drugih } \\
\text { komunikacija na daljinu, } \\
\text { 2) presretanje, prikupljanje } i \\
\text { snimanje računalnih podataka, } \\
\text { 3) ulazak u prostorije radi } \\
\text { provođenja nadzora i tehničko } \\
\text { snimanje prostorija, } \\
\text { 4) tajno praćenje i tehničko } \\
\text { snimanje osoba i predmeta, } \\
\text { 5) uporabu prikrivenih } \\
\text { istražitelja i pouzdanika, } \\
\text { 6) simuliranu prodaju i } \\
\text { otkup predmeta te simulirano } \\
\text { davanje potkupnine i } \\
\text { simulirano primanje } \\
\text { potkupnine, } \\
\text { 7) pružanje simuliranih } \\
\text { poslovnih usluga ili sklapanje } \\
\text { simuliranih pravnih poslova, } \\
\text { 8) nadzirani prijevoz i } \\
\text { isporuku predmeta kaznenog } \\
\text { djela. } \\
\text { (2) Iznimno, ako postoji } \\
\text { opasnost od odgode i ako } \\
\text { državni odvjetnik ima razloga }\end{array}$ \\
\hline
\end{tabular}

11 Sukladno Odluci USUD-a ovaj članak je u bitnome izmijenjen i dopunjen. Vidi Kos, Damir, et.al., Zakon o kaznenom postupku, Narodne novine, Zagreb, 2014. 


\begin{tabular}{|c|c|c|}
\hline ZKP/97 & ZKP/08 & ZKP/14 \\
\hline $\begin{array}{l}\text { počinitelja kaznenih djela iz } \\
\text { članka 192. ovoga Zakona } \\
\text { prenose priopćenja i poruke } \\
\text { u svezi s djelom, odnosno da } \\
\text { se počinitelj služi njihovim } \\
\text { priključcima na telefon ili } \\
\text { drugim telekomunikacijskim } \\
\text { uređajem. } \\
\text { (3) Pod uvjetima iz stavka } \\
\text { 1. ovoga članka, mjere iz } \\
\text { stavka 1. točke 1., 2., 3., } 5 . \\
\text { i 6. ovoga članka, mogu se } \\
\text { uz njegov pisani pristanak, } \\
\text { primijeniti na sredstva, } \\
\text { prostorije i predmete koji } \\
\text { su vlasništvo oštećenika ili } \\
\text { kojima se koristi oštećenik. } \\
\text { (4) U slučaju kada se ne } \\
\text { raspolaže saznanjima o } \\
\text { identitetu sudionika kaznenog } \\
\text { djela mjera iz stavka } 1 . \\
\text { točke 6. ovoga članka može } \\
\text { se odrediti prema predmetu } \\
\text { kaznenog djela. } \\
\text { (5) Izvršenje mjera iz stavka } \\
\text { 1. točke 4. i } 5 \text {. ovoga članka } \\
\text { ne smije predstavljati } \\
\text { poticanje na počinjenje } \\
\text { kaznenog djela. }\end{array}$ & $\begin{array}{l}\text { radnji započne odmah, nalog } \\
\text { iz stavka 1. ovog članka, prije } \\
\text { početka istrage na vrijeme } \\
\text { od dvadeset četiri sata može } \\
\text { izdati državni odvjetnik. } \\
\text { Nalog s oznakom vremena } \\
\text { izdavanja i obrazloženjem } \\
\text { državni odvjetnik mora u roku } \\
\text { od osam sati od izdavanja } \\
\text { dostaviti sucu istrage. Sudac } \\
\text { istrage odmah odlučuje } \\
\text { rješenjem o zakonitosti } \\
\text { naloga. Ako odobri nalog } \\
\text { državnog odvjetnika postupit } \\
\text { ce prema stavku 1. ovog } \\
\text { članka. Ako sudac istrage } \\
\text { odbije nalog, državni } \\
\text { odvjetnik, može u roku od } \\
\text { osam sati podnijeti žalbu. O } \\
\text { žalbi odlučuje vijeće u roku } \\
\text { od dvanaest sati. } \\
\text { (3) Ako vijeće ne odobri } \\
\text { nalog, u rješenju će naložiti } \\
\text { da se odmah obustave } \\
\text { radnje, a podaci prikupljeni } \\
\text { na temelju naloga državnog } \\
\text { odvjetnika će se predati sucu } \\
\text { istrage koji će ih uništiti. O } \\
\text { uništenju podataka sudac } \\
\text { istrage sastavlja zapisnik. } \\
\text { (4) Radnje iz točke 1. stavka } \\
\text { 1. ovog članka mogu se } \\
\text { odrediti i prema osobama } \\
\text { za koje postoje osnove } \\
\text { sumnje da počinitelju ili od } \\
\text { počinitelja kaznenih djela } \\
\text { iz članka 334. ovog Zakona } \\
\text { prenose priopćenja i poruke } \\
\text { u svezi s djelom, odnosno da } \\
\text { se počinitelj služi njihovim } \\
\text { priključcima na telefon ili } \\
\text { drugim telekomunikacijskim } \\
\text { uredajem, koje kriju } \\
\text { počinitelja kaznenog djela ili } \\
\text { mu prikrivanjem sredstava } \\
\text { kojima je kazneno djelo } \\
\text { počinjeno, tragova kaznenog } \\
\text { djela ili predmeta nastalih ili } \\
\text { pribavljenih kaznenim djelom } \\
\text { ili na drugi način pomažu da } \\
\text { ne bude otkriven. } \\
\text { (5) Pod uvjetima iz stavka } \\
\text { l. ovog članka, radnje iz } \\
\text { stavka 1. točke 1., 2.,, 3., 4., }\end{array}$ & $\begin{array}{l}\text { vjerovati da na vrijeme neće } \\
\text { moći pribaviti nalog suca } \\
\text { istrage, nalog iz stavka } 1 . \\
\text { ovog članka, može na vrijeme } \\
\text { od dvadeset četiri sata izdati } \\
\text { državni odvjetnik. } \\
\text { (3) Nalog iz stavka 2. ovog } \\
\text { članka državni odvjetnik } \\
\text { ne može izdati za posebne } \\
\text { dokazne radnje iz: } \\
\text { - stavka 1. točke 2) ovog } \\
\text { članka, ako način izvršenja te } \\
\text { radnje zahtijeva ulazak u dom, } \\
\text { ili udaljeni ulazak u računalo } \\
\text { osumnjičenika koje se nalazi u } \\
\text { njegovom domu, } \\
\text { - stavka 1. točke 3) ovog } \\
\text { članka, ako je radi provođenja } \\
\text { nadzora i tehničkog snimanja } \\
\text { potrebno ući u dom. } \\
\text { (4) Nalog s oznakom vremena } \\
\text { izdavanja i dopis u kojem } \\
\text { će obrazložiti razloge za } \\
\text { njegovo izdavanje državni } \\
\text { odvjetnik mora u roku od osam } \\
\text { sati od izdavanja dostaviti } \\
\text { sucu istrage. Ujedno će ako } \\
\text { smatra da treba nastaviti s } \\
\text { provođenjem posebne dokazne } \\
\text { radnje podnijeti sucu istrage } \\
\text { pisani obrazloženi zahtjev za } \\
\text { njezino daljnje provođenje. } \\
\text { Sudac istrage odmah po } \\
\text { primitku naloga i dopisa } \\
\text { ispituje jesu li postojali uvjeti } \\
\text { za izdavanje naloga te je li } \\
\text { postojala opasnost od odgode } \\
\text { iz stavka 2. ovog članka. } \\
\text { (5) Sudac istrage odlučuje } \\
\text { rješenjem o zakonitosti naloga } \\
\text { državnog odvjetnika. Ako } \\
\text { sudac istrage odobri nalog } \\
\text { državnog odvjetnika, a državni } \\
\text { odvjetnik je podnio zahtjev za } \\
\text { daljnje provođenje dokazne } \\
\text { radnje, postupit će prema } \\
\text { stavku 1. ovog članka. Ako } \\
\text { se sudac istrage ne složi s } \\
\text { nalogom državnog odvjetnika, } \\
\text { zatražit će da o tome odluku } \\
\text { donese vijeće. } \\
\text { Ako je zahtijevano daljnje } \\
\text { provođenje dokazne radnje } \\
\text { određene prema stavku 2. ovog }\end{array}$ \\
\hline
\end{tabular}




\begin{tabular}{|c|c|c|}
\hline ZKP/97 & ZKP/08 & ZKP/14 \\
\hline & $\begin{array}{l}\text { 6., 7. i 8. ovog članka, mogu } \\
\text { se uz pisani pristanak osobe, } \\
\text { primijeniti na sredstva, } \\
\text { prostorije i predmete te osobe. } \\
\text { (6) U slučaju kad se ne } \\
\text { raspolaže saznanjima o } \\
\text { identitetu sudionika kaznenog } \\
\text { djela, radnja iz stavka } 1 . \\
\text { točke 8. ovog članka može } \\
\text { se odrediti prema predmetu } \\
\text { kaznenog djela. } \\
\text { (7) Izvršenje radnji iz stavka } \\
\text { 1. točke 5. i } 6 . \text { ovog članka ne } \\
\text { smije predstavljati poticanje } \\
\text { na počinjenje kaznenog djela. }\end{array}$ & $\begin{array}{l}\text { članka ono se nastavlja } \\
\text { do odluke vijeća. Vijeće } \\
\text { o zahtjevu suca istrage } \\
\text { odlučuje u roku od dvanaest } \\
\text { sati od primitka zahtjeva. } \\
\text { Ako je vijeće potvrdilo nalog } \\
\text { državnog odvjetnika, a državni } \\
\text { odvjetnik je zahtijevao daljnje } \\
\text { provođenje dokazne radnje, } \\
\text { vijeće će izdati nalog iz stavka } \\
\text { l. ovog članka. Ako vijeće ne } \\
\text { odobri nalog, u rješenju će } \\
\text { naložiti da se odmah obustave } \\
\text { radnje, a podaci prikupljeni } \\
\text { na temelju naloga državnog } \\
\text { odvjetnika će se predati sucu } \\
\text { istrage koji će ih uništiti. O } \\
\text { uništenju podataka sudac } \\
\text { istrage sastavlja zapisnik. } \\
\text { (6) Posebne dokazne radnje } \\
\text { iz članka 332. stavka } 1 . \\
\text { točke } 3 . \text { ovog Zakona kada } \\
\text { je radi njezinog provođenja } \\
\text { potrebno ući u dom određuju } \\
\text { se isključivo po nalogu suda } \\
\text { koji je dužan voditi računa o } \\
\text { razmjernom ograničenju prava } \\
\text { na nepovredivost osobnog } i \\
\text { obiteljskog života. } \\
\text { (7) Radnje iz točke } 1 . \text { stavka } 1 . \\
\text { ovog članka mogu se odrediti } i \\
\text { prema osobama za koje postoje } \\
\text { osnove sumnje da počinitelju } \\
\text { ili od počinitelja kaznenih } \\
\text { djela iz članka 334. ovog } \\
\text { Zakona prenose priopćenja } \\
\text { i poruke u svezi s djelom, } \\
\text { odnosno da se počinitelj } \\
\text { služi njihovim priključcima } \\
\text { na telefon ili drugim } \\
\text { telekomunikacijskim uređajem, } \\
\text { koje kriju počinitelja kaznenog } \\
\text { djela ili mu prikrivanjem } \\
\text { sredstava kojima je kazneno } \\
\text { djelo počinjeno, tragova } \\
\text { kaznenog djela ili predmeta } \\
\text { nastalih ili pribavljenih } \\
\text { kaznenim djelom ili na drugi } \\
\text { način pomažu da ne bude } \\
\text { otkriven. } \\
\text { (8) Pod uvjetima iz stavka } 1 . \\
\text { ovog članka, radnje iz stavka } \\
\text { 1. točke 1., 2., 3., 4., 6., } 7 . \text { i } 8 . \\
\text { ovog članka, mogu se uz pisani }\end{array}$ \\
\hline
\end{tabular}




\begin{tabular}{|c|c|c|}
\hline ZKP/97 & ZKP/08 & ZKP/14 \\
\hline & & $\begin{array}{l}\text { pristanak osobe, primijeniti na } \\
\text { sredstva, prostorije i predmete } \\
\text { te osobe. } \\
\text { (9) U slučaju kad se ne } \\
\text { raspolaže saznanjima o } \\
\text { identitetu sudionika kaznenog } \\
\text { djela, radnja iz stavka } 1 . \\
\text { točke } 8 . \text { ovog članka može } \\
\text { se odrediti prema predmetu } \\
\text { kaznenog djela. (10) Izvršenje } \\
\text { radnji iz stavka 1. točke } 5 . \\
\text { i } 6 . \text { ovog članka ne smije } \\
\text { predstavljati poticanje na } \\
\text { počinjenje kaznenog djela. " }\end{array}$ \\
\hline
\end{tabular}

Imajući na umu da je pravo na pravično suđenje esencijalno definirano pretpostavkom prikupljanja dokaza shodno postupovnim pravilima naprijed citirane odredbe ZKP/97, ZKP/08 i ZKP/14 ukazuju na pretpostavke ostvarenja istog standarda zakonitosti postupanja, s time da zakonski izričaj «dokaz» valja razmotriti u najširem smislu značaja, odnosno, kao svaki izvor saznanja o činjenicama koje su, sukladno odredbama postupovnog zakonodavstva, predmet dokazivanja.

Nezakonite dokaze možemo podijeliti na:

a) dokaze pribavljene povredama ljudskih prava i sloboda propisanih međunarodnim ugovorima i Ustavom RH,

b) dokazi pribavljeni povredama ZKP-a,

c) dokazi, tzv. sekundarni, izvedeni i pribavljeni zakonito, no za taj se dokaz saznalo iz nekog dokaza (izvornog) pribavljenog na nezakonit način (doktrina "ploda otrovne voćke").

Međutim, pored prethodno definiranih okvira i razloga nezakonitosti dokaza, mnoge kontroverze u teoriji, ali i u sudskoj praksi, potenciralo je pitanje pravilnosti i zakonitosti (dokazno-pravne iskoristivosti) sadržaja tehničkih snimki telefonskih razgovora izrađenih na temelju valjanog sudskog naloga za provođenje posebne dokazne radnje (posebnog izvida) prema određenoj osobi i za određeno kazneno djelo, u odnosu na treću osobu i za kazneno djelo koje nije obuhvaćeno inicijalnim nalogom. Upravo o tom slučaju propitivanja zakonitosti dokaza, bit će riječi u nastavku rada.

S pravnog gledišta, načini prikupljanja podataka koji su podvedeni pod pravne norme, predstavljaju mjere na čiju se primjenu određeni subjekti ovlašćuju i za čiju se primjenu uređuju uvjeti. Čitav spektar mjera kojima policija i službe sigurnosti prikupljaju podatke moguće je razvrstati u dvije grupe:

1) one čijim se korištenjem manje ili neznatno zadire u individualna prava $i$ slobode,

2) one čijim se korištenjem privremeno i bez znanja osoba ograničavaju pojedina od zajamčenih individualnih prava i sloboda, posebno pravo na privatnost. 
U prvu grupu dolaze tradicionalne policijske mjere, kao što su: pozivanje na razgovor osoba radi dobrovoljnog davanja obavijesti (obavijesni razgovor), traženje obavještenja, uzimanje izjava od osumnjičenih (saslušanje), policijsko opserviranje, snimanje na javnim mjestima te prijave događaja od strane građana i slične mjere. Među mjerama te vrste koje više koriste službe sigurnosti nalaze se prikupljanje podataka iz javno dostupnih izvora, uključujući otvorene komunikacije putem interneta, traženje obavještenja od građana i tijela javnih vlasti, uvid u javne evidencije i druge zbirke podataka javnih vlasti i slično.

Druga grupa mjera ima posebni pravni tretman upravo jer se tim mjerama jače zadire $u$ individualna prava i slobode $\mathrm{i} u$ tom smislu se za njih koristi pojam posebne mjere (posebne dokazne radnje, posebni izvidi).

Po tome što se koriste bez (sa)znanja osoba ili organizacija o kojima se prikupljaju podatci, one su istovremeno i mjere kojima se tajno prikupljaju podatci. U tom smislu ih ovdje označavamo posebnim mjerama za tajno prikupljanje podataka.

Analizom domaćeg pozitivno-pravnog uređenja i usporednog zakonodavstva, kao posebne mjere za tajno prikupljanje podataka mogu se označiti:

1. tajna suradnja s fizičkim osobama (doušnici, informatori),

2. pribavljanje i otkup tajnih dokumenata,

3. uvid u evidencije osobnih i s njima povezanih podataka,

4. operativni prodor u organizacije i grupe (prikriveni istražitelj, infiltracija),

5. tajno praćenje i nadzor osoba na otvorenom prostoru i javnim mjestima uz korištenje tehničkih sredstava za foto-dokumentiranje i snimanje razgovora,

6. tajni nadzor, snimanje i pretres unutrašnjosti objekata, zatvorenih prostora i predmeta,

7. tajni nadzor sadržaja pisama i drugih sredstava komunikacija,

8. prisluškivanje, snimanje i nadzor razgovora, telekomunikacija i druga sredstva za prijenos podataka u zemlji ili inozemstvu, $\mathrm{i}$

9. specijalne mjere, odnosno dokazne radnje, za borbu protiv organiziranog kriminala i određenih drugih teških kaznenih djela (pružanje simuliranih poslovnih usluga i sklapanje simuliranih pravnih poslova, kontrolirana isporuka, saslušanje svjedoka suradnika).

U nalaženju rješenja za adekvatno zakonsko reguliranje mjera tajnog prikupljanja podataka izvjesno mogu pomoći određeni stavovi i načela, koji su posebno razvijeni u europskom zakonodavstvu i praksi primjene članka 8 . EKZLJP-a i koji se, stoga, mogu smatrati europskim standardima u ovoj materiji.

Prema stavku 2. članka 8. EKZLJP-a, javne vlasti se neće miješati u vršenje (uživanje) prava na privatnost: "osim ako to nije u skladu sa zakonom i neophodno $u$ demokratskom društvu u interesu nacionalne sigurnosti, javne sigurnosti ili ekonomske dobrobiti zemlje, radi sprječavanja nereda ili kriminala, zaštite zdravlja ili morala, ili radi zaštite prava i sloboda drugih". Iz ove odredbe slijede tri bitna načela, prema kojima miješanje u privatnost mora biti:

(1) legalno, tj. uređeno zakonom,

(2) svedeno na nužnu mjeru (načelo razmjernosti) i 
(3) jedino moguće radi postizanja navedenih interesa (koji predstavljaju osnovu za miješanje u pravo na privatnost).

Međutim, tumačenje tih osnova za miješanje u pravo na privatnost putem mjera tajnog prikupljanja podataka dovodi nas do zaključka da su oni u citiranoj odredbi dani prilično (ne)određeno i (pre)široko. Upravo je zato važno pratiti noviji usporedni razvoj zakonodavstva europskih zemalja i praksu ESLJP-a, ${ }^{12}$ koji su znatno precizirali značenje članka 8. EKZLJP-a, vezujući mogućnost miješanja u pravo na privatnost za sljedeća osnovna pravila:

- slučajevi u kojima se miješanje u pravo na privatnost može dopustiti, moraju biti zakonom unaprijed uređeni kako bi za građane bili dovoljno predvidivi, a ti zakoni moraju po svom sadržaju biti odgovarajući zahtjevima vladavine prava,

- slučajevi miješanja u pravo na privatnost moraju biti uređeni restriktivno i vezani uz teška kaznena djela i prijetnje po sigurnost da bi time bili u materijalnopravnom smislu legitimni,

- postupak za primjenu mjere mora biti propisan zakonom,

- o primjeni mjere u konkretnom slučaju treba odlučiti sud ili drugi organ na temelju postojanja osnova sumnje,

- početak i maksimalno trajanje mjere moraju biti unaprijed određeni u odluci suda ili drugog tijela,

- nad primjenom mjere treba postojati kontrola suda ili drugog tijela,

- za prekoračenje i zloupotrebu u primjeni mjere treba biti propisana sankcija,

- postupak za zaštitu građana treba biti propisan zakonom i obuhvaćati mogućnost sudske zaštite i

12 ESLJP je kratica od The European Court of Human Rights. Europski sud za ljudska prava je međunarodno sudsko tijelo ustanovljeno 21. siječnja 1959. Sud je uspostavljen Europskom konvencijom za zaštitu ljudskih prava i temeljnih sloboda (Convention for the Protection of Human Rights and Fundamental Freedoms - dalje: Europska konvencija ), koja je usvojena pod okriljem Vijeća Europe 4. studenog 1950., a stupila na snagu 3. rujna 1953. Konvencija je stvarana pod velikim utjecajem Univerzalne deklaracije o pravima čovjeka, tako da su prava zaštićena Europskom konvencijom u osnovi sadržana u prvoj polovini Opće deklaracije - građanska i politička. Sud je postao stalna institucija zaštite ljudskih prava u Europi 1. studenog 1998., kada je stupio na snagu Protokol br. 11. Europske konvencije. Prije uvođenja ovog protokola, sudsku funkciju je, pored Suda, obavljala i Europska komisija za ljudska prava ( 1954. ). Protokol br.11. ukinuo je Komisiju, ali je ona nastavila s radom do 31. listopada 1999. radi okončanja tekućih postupaka. U prve tri godine samostalnog postojanja Europskog suda za ljudska prava, broj sporova je povećan za oko $130 \%$. Tijekom 1998. bilo je evidentirano 5.979 predmeta, a 2001. godine 13.858. Pitanje reforme sudskog sustava otvoreno je 2000., pa je Protokol br. 14. predložen kao mehanizam rasterećenja Suda i unaprjeđenja njegove učinkovitosti. Protokol br. 14. predviđa prijenos nadležnosti s vijeća na suce pojedince, smanjenje broja članova vijeća, pooštravanje uvjeta za pokretanja međunarodnih sporova. Sjedište Suda nalazi se u Strasbourgu u Francuskoj. Pobliže vidi kod: Dijk van, Peter, et al., Theory and Practice od the European Convection on human Rights, Kluwer Law International, The Hague, 1998., Sadiković, Ćazim, Europsko pravo ljudskih prava, Magistrat, Sarajevo, 2008. Za potrebe ovoga rada rabit ćemo jedinstveni izričaj ESLJP i za sud i za Europsku komisiju za ljudska prava. 
- građanin treba imati pravo biti obaviješten o mjeri i rezultatima njezine primjene ( podatcima koji su prikupljeni mjerom ), a čuvanje osobnih podataka u tajnim dosjeima predstavlja narušavanje prava na poštovanje privatnog života.

Postojeće zakonsko uređenje mjera tajnog prikupljanja podataka kod nas, kao što se dalje pokazuje, još uvijek nije usklađeno s izloženim zahtjevima, osobito u pogledu pojedinih od tih zahtjeva, iako se radi o skoro (netom, upravo) donesenim zakonima.

\section{PRAKSA VRHOVNOG SUDA REPUBLIKE HRVATSKE (VSRH)}

$\mathrm{VSRH}^{13}$ je u jednom pravorijeku izrekao:

"U razmatranju problematike primjene odredaba Zakona o kaznenom postupku koji se odnose na privremeno ograničavanje ustavnih prava i sloboda radi pribavljanja podataka i dokaza za provedbu kaznenog postupka Vrhovni sud Republike Hrvatske, kao sud drugog stupnja, mišljenja je da se dokaz koji je pribavljen u okviru izvidne mjere naložene prema osobi za koju postoji osnovana sumnja da je sama počinila ili zajedno s drugim osobama sudjelovala u kaznenom djelu iz čl. 181. ZKP - katalog kaznenih djela, može valjano uporabiti, ne samo prema osobi prema kojoj je mjera naložena, već i prema svakoj trećoj osobi koja se zatekla u sferi kriminalne djelatnosti osobe prema kojoj je neka od mjera iz čl. 180. st. 1. ZKP usmjerena, a kriminalna aktivnost te treće osobe ulazi u ostvarenje obilježja kaznenog djela predviđenog katalogom kaznenih djela iz čl. 181. ZKP ali uvijek isključivo pod uvjetom da se ta treća osoba našla zajedno s osobom protiv koje je neka od mjera iz čl. 180. st. 1. toč. 1. do 6. ZKP valjalo naložena..."

“...Provodeći naložene mjere prema okr. N.P. redarstvene vlasti, koje su provodile mjeru trajnog praćenja i tehničkog snimanja osoba i predmeta iz čl. 180. st. 1. toč. 3. Zakona o kaznenom postupku, a ni prikriveni istražitelji 1 i 2, koji su provodili mjere uporabe prikrivenih istražitelja i simuliranog otkupa predmeta iz čl. 180. st. 1. toč. 4. i 5. Zakona o kaznenom postupku nisu u razdoblju od 20. veljače do 8. ožujka 2002. godine naloženim mjerama nigdje naišli na okr. N.P. pa, slijedom ranije izloženog mišljenja ovog suda drugog stupnja, na treće osobe "zahvaćene" ovim mjerama te se mjere ne mogu odnositi, pa zato niti obavijesti i podaci do kojih se došlo u provođenju ovih mjera ne mogu se upotrijebiti kao dokaz u predmetnom kaznenom postupku i trebalo ih je kao nezakonite izdvojiti iz spisa, kao što je to ispravno učinio prvostupanjski sud."

$\mathrm{U}$ još jednom pravorijeku ${ }^{14}$ koji problematizira istu tematiku VSRH je, između ostalog, odlučio:

"Nije u pravu taj žalitelj kada tvrdi da je sud počinio bitnu povredu odredaba kaznenog postupka iz čl. 367. st. 2. ZKP-a time što je svoju odluku temeljio na rezultatima izvidnih mjera iz čl. 180. st. 1. ZKP-a koje su određene prema opt. T. 
P., pa smatra da je korištenje rezultata tih mjera u odnosu na njega tijekom ovog dokaznog postupka nezakoniti dokaz.

Točno je da je nalogom istražnog suca broj Kir-1415/03 naloženo provođenje mjera iz čl. 180. st. 1. toč. 3., 4. i 5. ZKP-a prema T. P., ali optuženik pogrešno drži da se rezultati provedenih mjera mogu koristiti samo u odnosu na tog optuženika.

Dokazi pribavljeni provođenjem mjera iz čl. 180. ZKP-a mogu se valjano uporabiti ne samo prema osobi za koju su mjeru naložene već i prema svakoj trećoj osobi koja se zatekla u sferi kriminalne djelatnosti osobe prema kojoj je mjera usmjerena, pod uvjetom da kriminalna aktivnost te osobe, u konkretnom slučaju žalitelja, ulazi u ostvarenje bića kaznenog djela za koje je mjera naložena. U konkretnom slučaju mjere su naložene zbog sumnje da je opt. T. P. u više navrata vršio otkup veće količine droge heroin od nepoznate osobe albanske narodnosti, pa kako je tijekom postupka utvrđeno da je ta nepoznata osoba upravo žalitelj svi pribavljeni dokazi provođenjem određenih mjera mogu se valjano uporabiti i prema пјети."

U drugom pravorijeku ${ }^{15}$ isti je Sud zauzeo motrište:

"Također, dokazi pribavljeni posebnim izvidima kaznenih djela privremenim ograničavanjem ustavnih prava $i$ sloboda tehničkim snimanjem telefonskih razgovora opt. $D$.

S. i uporabom prikrivenog istražitelja u skladu s odredbom čl. 180. st. 1. t. 1. i 4. ZKP, suprotno tvrdnji žalitelja, zakoniti su dokazi. Naime, prema stajalištu Vrhovnog suda Republike Hrvatske, kao drugostupanjskog suda, do saznanja kojima se došlo primjenom mjera kojim se privremeno ograničavaju ustavna prava i slobode određenih osoba za koje se osnovano sumnja da su sami ili zajedno s drugim osobama počinitelji kaznenih djela navedenih u čl. 181. ZKP, mogu uporabiti i prema trećim osobama, a ne samo prema onima za koje postoji nalog za provođenje tih mjera. To se odnosi isključivo na situaciju kada se treće osobe nađu u sferi kriminalne aktivnosti osobe prema kojoj se mjera iz čl. 180. st. 1. ZKP provodi, a kriminalno djelovanje te treće osobe ostvaruje obilježja kaznenog djela predviđenog u katalogu kaznenih djela iz čl. 181 ZKP. Prema tome, kako se do saznanja o djelovanju opt. S. J. došlo slušanjem telefonskih razgovora opt. D. S., a zatim je provedena uporaba prikrivenog istražitelja zbog osnovane sumnje o počinjenju kaznenog djela protiv vrijednosti zaštićenih međunarodnim pravom (Glava XIII), po valjanom nalogu istražnog suca u odnosu na opt. S. J. sukladno odredbama čl. 180. do 182.a ZKP, radi se o zakonitim dokazima na kojima se može temeljiti presuda."

U trećem pravorijeku ${ }^{16}$ isti Sud navodi:

"Naime, u pravu je opt. M.S. kada tvrdi da razgovori koji su snimljeni prilikom neuspjelog pokušaja uspostavljanja telefonske veze s biranim brojem, a vode se između opt. M. S. i NN osobe istovremeno dok taj optuženik čeka uspostavljanje telefonske veze, ne mogu biti zakoniti dokazi, jer se time postupa 
protivno opsegu naloga izdanog za provođenje izvidne mjere iz čl. 180. st. 1. toč. 1 . ZKP-a. Naime, nalogom istražnog suca za nadzor i tehničko snimanje telefonskih razgovora obuhvaćeni su samo oni sadržaji koji su rezultat snimanja uspostavljenog telefonskog kontakta između nadziranog i biranog telefonskog broja, a ne i oni sadržaji koji su slučajno dobiveni bez uspostavljene telefonske veze, budući da se ti sadržaji ne mogu smatrati telefonskim razgovorima kakve ima u vidu odredba čl. 180. st. 1. toč. 1. ZKP-a. U protivnom značilo bi da se bilo kojim, pa i nehotičnim aktiviranjem opcije pozivanja s nadziranog telefonskog broja, a bez ostvarivanja željenog telefonskog kontakta, mogu snimati razgovori osoba koje su u zvučnom dosegu mikrofona telefonskog aparata, čime bi se izvidnom mjerom iz čl. 180. st. 1. toč. 1. ZKP-a, u stvari, nezakonito prikupljali podaci na način predviđen posebnom izvidnom mjerom iz čl. 180. st. 1. toč. 1. ZKP-a, u kojem pravcu nije izdan odgovarajući nalog istražnog suca.

Odredbe zakona o provođenju posebnih izvida iz čl. 180. st. 1. toč. 1. ZKP-a trebaju se tumačiti restriktivno tj. strogo u skladu sa zakonskim tekstom, jer bi se u protivnom na nedopušteni način širila zona privremenog ograničavanja ustavnih prava i sloboda građana, a posljedično i kršila osnovna ljudska prava na zaštitu osobnog života i tajnosti općenja garantirana čl. 35. i 36. Ustava Republike Hrvatske te čl. 8. Konvencije o zaštiti ljudskih prava i temeljnih sloboda.

Budući da je prvostupanjski sud izričito citirao i analizirao sadržaje razloga koji su snimljeni između opt. M.S. i N.N. osobe za vrijeme dok telefonska veza s nadziranog broja nije bila uspostavljena te je na temelju tako pribavljenih podataka izveo zaključke o postojanju međusobne udruženosti optuženika radi činjenja kaznenih djela zlouporabe opojnih droga (list 136 i 137 obrazloženja), to je ostvarena apsolutno bitna povreda odredaba kaznenog postupka iz čl. 367. st. 2. ZKP-a jer se presuda temelji na nezakonitom dokazu." 17

\section{PRAKSA USTAVNOG SUDA REPUBLIKE HRVATSKE (USUD)}

USUD u sljedećem pravorijeku definira doseg testiranja (ne)zakonitosti provođenja posebnih mjera (posebnih dokaznih radnji, posebnih izvida), sudova $\mathrm{i}$ USRH-a, dovodeći ga u kontekst dispozicija obrane u postupku (pasivnost pozivati se na nevaljanosti naloga za provođenje posebnih mjera kao prekluzivni razlog). ${ }^{18}$

"8.1. Kada, naime, nalog istražnog suca o primjeni posebnih izvidnih mjera, osim izreke u kojoj se nabrajaju posebne izvidne mjere koje će se primijeniti protiv

17 Pored prethodno navedenih judikata Vrhovnog suda Republike Hrvatske, sudska praksa nižih sudova zaključuje stavom da govor snimljen na traci govornog automata (telefonska sekretarica) nije dokaz pribavljen na nezakonit način jer osoba koja na taj način ostavlja poruku čini to vlastitom voljom i sa znanjem da će njezin govor biti snimljen na audio traci, te da će takva poruka biti proslijeđena točno određenoj osobi. Županijski sud u Zagrebu, IV Kž 1431/02 od 11. listopada 2002. Vidi u: Izbor odluka Vrhovnog suda Republike Hrvatske, 2002., br. 2., str. 213.

18 USRH, U-III-857/2008, od 1. listopada 2008. - izvorno. 
određene osobe, u obrazloženju ne sadrži ništa drugo do konstatacije koja ponavlja da je USKOK podnio zahtjev za primjenom posebnih izvidnih mjera protiv neke osobe ,jer da postoje osnove sumnje da je počinila kazneno djelo" te da te osnove sumnje proizlaze iz „prijedloga Sektora krim. Policije PU SD te posebno zapisnika o zaprimanju kaznene prijave", onda je razvidno da time takav nalog krši ustavno jamstvo nepovredivosti osobnog i obiteljskog života iz članka 35. Ustava, te slobodu i tajnost svih oblika općenja iz članka 36. stavka 1. Ustava.

8.2. Ustavni sud upozorava da se jamstva osobnih prava mogu ograničiti samo radi ostvarenja cilja propisanog zakonom i razmjerno naravi potrebe za takvim ograničenjem, o čemu pravilno i zakonito odlučuje sud (v. mutatis mutandis, odluku Ustavnog suda broj: U-III-4286/2007 od 26. prosinca 2007.). Sporni je nalog, prema citiranim odredbama Zakona o kaznenom postupku, morao u konkretnom slučaju sadržavati (a) valjanu ocjenu ,osnova sumnje da je [podnositelj] sam počinio ili zajedno s drugim osobama sudjelovao" u nekom od kataloških kaznenih djela iz članka 181. Zakona o kaznenom postupku, te (b) ocjenu da se izvidi kaznenih djela ,ne bi mogli provesti na drugi način ili bi bili skopčani s nerazmjernim teškoćama". Samo takav njegov sadržaj građanima jamči da će postojanje „osnova sumnje“ na kataloško kazneno djelo prethoditi određivanju neko od posebnih izvidnih mjera, da će postojati određeni minimalni stupanj vjerojatnosti takvog konkretnog - a ne pretpostavljanog - kaznenog djela te da će nalog, kao jasno artikulirano raspolaganje sredstvima državne prisile, biti logičan i uvjerljiv te u kasnijem stadiju postupka, provjerljiv pred drugim sudskim tijelima.

8.3. Kada tako nije postupljeno, onda je nalog o primjeni posebnih izvidnih mjera prekršio Zakon o kaznenom postupku. Posljedica toga već je izrijekom predviđena u tome zakonu. Na izričaj u članku 180.a ,... pod uvjetima i na način iz članka 180. stavka 1. točke 1., 2., 3., 4., 5. i 6...", te izričaj u članku 182. stavku 6. ,...Ako su mjere iz članka 180. ovoga Zakona poduzete bez naloga istražnog suca ili je postupljeno protivno odredbi članka 180... ". Zakon o kaznenom postupku nadovezuje nedopuštenost uporabe u kaznenom postupku dokaza pribavljenih nezakonito određenim posebnim izvidnim mjerama i time zaštićuje spomenuta ustavna prava građana u inače dopuštenoj primjeni posebnih izvidnih mjera.

9. No, podnositelj nije taj prigovor iz ustavne tužbe iznio niti na glavnoj raspravi pred prvostupanjskim sudom niti u žalbi na presudu (v. gore točke 2. $i$ 5.) nego po prvi put u ustavnoj tužbi. Štoviše, on ga nije koristio niti u drugim, posebnim pravnim sredstvima koja Zakon o kaznenom postupku pruža okrivljeniku tijekom postupka za osporavanje valjanosti dokaza koji se unose u spis predmeta. Iz spisa predmeta pred prvostupanjskim sudom vidljivo je da podnositelj nije koristio zahtjev za izdvajanje zapisnika o nezakonitim dokazima i službenim zabilješkama policije tijekom istrage - na čijem je kraju istražni sudac po službenoj dužnosti, rješenjem broj: Kio-US-3/04 od 22. ožujka 2004., izdvojio (članak 78. stavak 1.) određene policijske dokaze iz policijskih izvida koji su prethodili istrazi. Također, podnositelj je mogao protiv optužnice USKOK-a, broj: UK-18/04 od 9. travnja 2004., podnijeti prigovor te osporiti zakonitost naloga o određivanju posebnih 
izvidnih mjera, o kojem bi odlučilo izvanraspravno vijeće prije glavne rasprave (članak 274. stavak 4.) i eventualno izdvojilo nezakonite dokaze, ali to nije učinio.

Tim propustima podnositelj je bitno umanjio mogućnost redovnih sudova da reagiraju na povredu zakona (gore točka 8.1.) koju je istaknuo tek u ustavnoj tužbi. Zakon o kaznenom postupku u članku 379. stavku 1. doduše propisuje da drugostupanjski sud mora po službenoj dužnosti ispitati postojanje nekih bitnih povreda kaznenog postupka, među kojima i one iz članka 367. stavka 2., koji se odnose na uporabu nezakonitih dokaza. No, ta dužnost ne može biti neograničena: kada je, naime, u konkretnom slučaju, žalba podnositeljeva branitelja istakla prigovor pobijanja prvostupanjske presude po osnovi nezakonitih dokaza, ali se pri tome ograničila samo na isticanje zabranjene provokacije na kazneno djelo, odnosno povredu odredbe članka 180. stavka 5. Zakona o kaznenom postupku (gore točka 5.3.), onda je u takvoj procesnoj situaciji drugostupanjski sud izgubio legitimnu osnovu proširivanja prigovora nezakonitosti dokaza, jer bi time prekršio načelo stranačke dispozitivnosti u žalbenom postupku. Njega utvrđuje Zakon o kaznenom postupku izričajem spomenutog članka 379. stavka 1., koji glasi: "Drugostupanjski sud ispituje presudu u onom dijelu u kojem se pobija žalbom i iz osnova iz kojih se pobija.“. Premda poštivanje prava čovjeka i vladavina prava, kao najviše vrednote ustavnog poretka, Republici Hrvatskoj i njezinim državnim (pravosudnim) tijelima nalažu stalnu dužnost da skrbe za točnost presuda njezinih sudova u pogledu rješavanja pravnih pitanja - u koja neprijeporno spadaju i pitanja zakonitosti pribavljanja i uporabe dokaza u kaznenom postupku - ipak se načelo stranačke dispozitivnosti u određenom dijelu kaznenog postupka, kako ga je ustanovio zakonodavac, ne smije ograničiti ekstenzivnim tumačenjem navedene dužnosti sudova niti se pred Ustavnim sudom ustavnopravnim tumačenjem zakonskih normi može određivati - proširivati ili sužavati - koncept stranačke autonomije kojeg zakonodavac zastupa u konstrukciji (sudskog) kaznenog postupka.

10. Stoga Ustavni sud ocjenjuje da navedenim propustom podnositelj nije iscrpio dopušteni pravni put $u$ dijelu svojih prigovora prvostupanjskoj $i$ drugostupanjskoj presudi. No, kako je ustavnu tužbu razmotrio u cijelosti, imajući $u$ vidu i druge iznesene razloge koje je ocijenio neosnovanima, nije ju na temelju članka 72. Ustavnog zakona u tom dijelu odbacio kao nedopuštenu nego je, utvrdivši da osporenim presudama podnositelju nije povrijeđeno ustavno pravo zajamčeno člankom 29. stavkom 4. Ustava, kao niti ustavno pravo na pravično suđenje zajamčeno odredbom članka 29. stavka 1. Ustava, na temelju odredbi članaka 73. $i$ 75. Ustavnog zakona, odlučio o ustavnoj tužbi u cijelosti kao u izreci."

U sljedećem je pravorijeku USRH ukazao na zakonitost (valjanost) zapisa privatne snimke dviju osoba, uz obostranu suglasnost. ${ }^{19}$

"Naime, u tijeku kaznenog postupka, Županijski sud je, rješenjem od 5. rujna 2002., odbio prijedlog branitelja podnositelja i četvrtooptuženika da se ta kazeta izdvoji iz spisa, kao nezakonit dokaz. To rjě̌enje Županijskog suda potvrdio je

19 USRH, U-III-2710/2004, od 21. rujna 2006. - izvorno. 
Vrhovni sud Republike Hrvatske, rješenjem broj: I Kž-808/02-5 od 22. listopada 2002. godine. Sudovi su utvrdili da predmetna kazeta ne predstavlja nezakonit dokaz u smislu odredbe članka 9. stavka 2. Zakona o kaznenom postupku ("Narodne novine”, broj 110/97., 27/98., 58/99., 112/99., 58/02. i 143/02., u daljnjem tekstu: ZKP), odnosno dokaz na kojem se ne može temeljiti sudska presuda u smislu članka 78. stavka 1. ZKP. Sudovi su naime utvrdili da je do predmetnog razgovora I. D. i S. R. došlo u studenom 1991. kada je S. R. obnašao dužnost pomoćnika ministra unutarnjih poslova, zaduženog za krim. policiju, a I. D. dužnost načelnika Policijske uprave Gospića. Do razgovora je došlo na inicijativu I. D., koji je, s obzirom na svoju funkciju, želio upoznati višepozicioniranog djelatnika redarstvenih vlasti s podacima i događanjima na terenu u Gospiću, posebno o nestanku i likvidaciji civilnih osoba, pa je taj razgovor sniman na audio kazetu na prijedlog S. R. i uz suglasnost I. D. Vrhovni sud je ocijenio da je iz ovakvog stanja stvari jasno da je I. D., kao načelnik PU Gospić, imao sve ovlasti, operativnim radom $i$ sukladno svojim ovlastima, provesti kriminalističku obradu u pravcu utvrđivanja kaznenih djela $i$ počinitelja, što znači da postupa u smislu članka 177. ZKP, dok S. R. u okviru svog statusa i položaja te ovlasti nije imao, ali je mogao narediti da se takve neposredne operativne radnje provedu.

Stajalište je sudova da se ne radi o obavijesnom razgovoru u smislu članka 177. stavka 2. ZKP, prema kojoj su redarstvene vlasti ovlaštene, u okviru kriminalističke obrade, pozivati građane radi davanja obavijesti o kaznenom djelu i počinitelju. Vrhovni sud je pritom zauzeo stajalište da dikcija te zakonske odredbe ne predviđa da bi se takav razgovor mogao voditi između dvaju rukovodećih djelatnika redarstvenih vlasti kao što je konkretan slučaj. U konkretnom slučaju razgovor nije vođen u okviru kriminalističke obrade u smislu članka 177. stavka 2. ZKP niti je predstavljao podnošenje kaznene prijave protiv nepoznatih odnosno poznatih počinitelja kaznenih djela, već se radilo o konzultativnom razgovoru radi upoznavanja s aktualnim stanjem na terenu u svezi s nestankom i likvidacijom pojedinih civilnih osoba.

Budući da je sporna kazeta snimljena uz suglasnost obaju sugovornika, sudovi su ocijenili da se ista ne može smatrati nezakonitim dokazom u smislu članka 9. stavka 2. ZKP, jer ni jednom od sudionika razgovora nisu povrijeđena prava zajamčena Ustavom ili međunarodnim pravom, niti je kazeta pribavljena povredom odredaba kaznenog postupka.

Zaključak je sudova da ta kazeta predstavlja dokument koji je podoban da se izvede kao dokaz u kaznenom postupku i podvrgne ocjeni suda kao i svi drugi dokazi koji su od relevantnog utjecaja na donošenje sudske odluke."

\section{PRAKSA EUROPSKOG SUDA ZA LJUDSKA PRAVA (ESLJP)}

ESLJP se izjašnjavao i u predmetima u kojima su iznesene tvrdnje da prikupljanje i korištenje osobnih podataka ili prisluškivanje fizičkih osoba od strane državnih tijela nije u skladu s odredbama članka 8 (1) Konvencije - pravom na poštovanje privatnosti, prepiske i/ili doma. 
U dva predmeta, Klass i drugi protiv SR Njemačke (1978. ${ }^{20}$ i Malone protiv Ujedinjenog Kraljevstva (1984.), ${ }^{21}$ podnositelji zahtjeva tvrdili su da su njihova prava na privatni život i prepisku (opisana u istom predmetu kao pravo na sve oblike privatnog komuniciranja) po članku 8. prekršena tajnim prisluškivanjem tijekom kaznenog postupka. U prvom predmetu ESLJP je utvrdio da je zapadnonjemački zakon o prisluškivanju dostatno precizan i da je postupak kojim se osigurava da su sve mjere prikupljanja informacija u skladu sa zakonom dovoljno striktan da bi bili ispunjeni zahtjevi zakonitosti prema članku 8 (2). ESLJP je utvrdio da potreba države da se zaštiti od "neposrednih opasnosti" koje prijete "slobodnom demokratskom ustavnom poretku", predstavlja zakoniti cilj države po odredbi o ograničenju koje je "potrebno u demokratskom društvu u interesu nacionalne sigurnosti i radi sprječavanja nereda i kaznenih djela”. Konačno, ESLJP je našao da je spomenuti postupak dovoljan da osigura da mjere države ostanu u srazmjeru s tim zakonitim ciljevima.

U predmetu Malone riječ je bila o istim pitanjima kao i u predmetu Klass. $\mathrm{Tu}$ se ESLJP trebao izjasniti o zakonitosti policijskog prisluškivanja telefonskih razgovora i uspostavljanju "registra" telefonskih brojeva pozvanih s određenog telefona. Sud je utvrdio da je propis Ujedinjenog Kraljevstva kojim se regulira prisluškivanje telefonskih razgovora, previše nejasan da bi odgovorio standardu "suglasnosti sa zakonom":

"Bilo bi suprotno vladavini prava kada bi se diskrecijska sloboda, dana izvršnoj vlasti, izražavala kao neobuzdana moć. Slijedi da zakon mora dovoljno jasno ukazati na granice takove diskrecijske slobode dane nadležnim tijelima $i$ na način njenog korištenja, imajući u vidu zakoniti ciljodređene mjere, da bi se pojedincu pružila odgovarajuća zaštita od samovoljnog miješanja."

ESLJP je nadalje utvrdio da, iako je registriranje telefonskih poziva, za razliku od prisluškivanja, uobičajeno u poslovnoj praksi, dostavljanje takvih podataka policiji, bez zakonskog reguliranja ili suglasnosti osoba čiji se razgovori bilježe, predstavlja neopravdano miješanje u privatnu sferu po članku 8 . Sud je utvrdio da su i prisluškivanje i registriranje u ovom predmetu bili suprotni zahtjevu zakonitosti, te je smatrao da nije potrebno da se upušta u to jesu li ove mjere bile "potrebne $u$ demokratskom društvu".

U predmetima Huvig protiv Francuske (1990.) $)^{22}$ i Kruslin protiv Francuske (1990.), ${ }^{23}$ činjenice su bile slične kao u predmetu Malone. U oba slučaja ESLJP je utvrdio da propisi i praksa u Francuskoj nisu u skladu s uvjetom zakonitosti iz članka 8. ESLJP je kršenje članka 8. utvrdio i kada je građanin tajno snimao telefonske razgovore uz pomoć visoko pozicioniranog djelatnika policije (A. protiv Francuske (1993.) ${ }^{24}$ i kada je policija prisluškivala telefonske pozive zaposlenog

20 Zahtjev br. 5029/71, od 6. rujna 1978., vidi na: http://hudoc.echr.coe.int

21 Zahtjev br. 8691/79, od 2. kolovoza 1984., vidi na: http://hudoc.echr.coe.int

22 Zahtjev br. 11105/84, od 24. travnja 1990., vidi na: http://hudoc.echr.coe.int

23 Zahtjev br. 11801/85, od 24. travnja 1990., vidi na: http://hudoc.echr.coe.int

24 Zahtjev br. 14838/89, od 23. studenog 1993., vidi na: http://hudoc.echr.coe.int 
u policijskoj upravi (Halford protiv Ujedinjenog Kraljevstva (1997.)). ${ }^{25} \mathrm{U}$ ovom posljednjem predmetu, ESLJP nije prihvatio vladin argument da je policija imala pravo prisluškivati telefone $\mathrm{u}$ njihovim vlastitim prostorijama bez prethodnog dobivanja naloga, utvrđujući da je ta praksa nezakonita u smislu Konvencije.

ESLJP, u načelu, ostavlja državama jako široko polje slobodne procjene pri prikupljanju i korištenju podataka izvan kaznenog postupka. U predmetu Leander protiv Švedske (1987.), ${ }^{26}$ podnositelj zahtjeva se žalio jer je država prikupila tajne podatke o njemu i koristila se njima da bi mu uskratila pristup državnoj službi.

ESLJP je utvrdio da je detaljnost odgovarajuće uredbe u skladu sa zahtjevom zakonitosti. Nalazeći da članak 8. nije povrijeđen, također je zapazio da se EKZLJPom ne jamči pravo stupanja u javnu službu te da mjere koje je država poduzela u ovom predmetu "ne predstavljaju prepreku vođenju privatnog života po slobodnom izboru" podnositelja zahtjeva.

Ovdje valja ukazati na odredbu članka 8. EKZLJP-a, koja, u bitnom propisuje mogućnost dopuštenog zadiranja u pravo na poštovanje privatnog života i tajnosti dopisivanja uz kumulativno ispunjenje sljedećih pretpostavki:

a) da je isto propisano nacionalnim zakonom,

b) da je isto nužno u demokratskom društvu radi interesa državne sigurnosti, javnog reda i mira, ili gospodarske dobrobiti zemlje te radi sprječavanja nereda ili zločina, radi zaštite zdravlja ili morala ili radi zaštite prava i sloboda drugih.

U mnogobrojnim odlukama ESLJP je pružio zaštitu tajnosti telefonskog komuniciranja zaštićenog odredbom članka 8 . EKZLJP. ${ }^{27}$

O nedostatku zakonske osnove za provođenje opisanih mjera sud je zauzeo stav u predmetu Satik protiv Turske ${ }^{28}$ te je izrekao:

“57. U konkretnom slučaju, Vlada se oslanja na članke 4. i 6. Zakona br. 2937 kao pravnoj osnovi prisluškivanja i snimanja podnositeljevih telefonskih razgovora $i$ tvrdi da su sporne mjere bile opravdane u uvjetima za zaštitu nacionalne sigurnosti. Međutim, Sud je već utvrdio da u vrijeme činjenica koje su dovele do ove prijave nije bilo domaćih zakona koji su regulirali telefonsko prisluškivanje i snimanje (vidjeti A Ğaoğlu protiv Turske, br. 27310/95, \& \& 54-55, 06. prosinac 2005.). Tako je nedostatak pravne osnove za takvo uplitanje dovelo Sud do zaključka da je telefonsko snimanje koje je u pitanju bilo nezakonito pribavljanje dokaza, $u$ okolnostima slučaja."

O statusu trećeg (treće strane) koji se pojavio na prisluškivanom telefonskom broju ESLJP je iskazao svoje stajalište u dva bitna predmeta.

25 Zahtjev br. 20605/92, od 25. lipnja 1997., vidi na: http://hudoc.echr.coe.int

26 Zahtjev br. 9248/81, od 26. ožujka 1987., vidi na: http://hudoc.echr.coe.int

27 Primjerice, predmeti Valenzuela Contreras protiv Španjolske, zahtjev br. 27671/95, od 30. srpnja 1998., Kruslin protiv Francuske, zahtjev br. 11801/85, od 24. travnja 1990., Lambert protiv Francuske, zahtjev br. 23618/94, od 24. kolovoza 1998., Kopp protiv Švicarske, zahtjev br. 23224/94, od dana 25. ožujka 1998. i sl.

28 Zahtjev br. 36961/97, od 25. travnja 2002., vidi na: http://hudoc.echr.coe.int 
U predmetu Kopp protiv Švicarske, ${ }^{29}$ rečeno je:

"Prvo, nije na Sudu da nagađa u kojem je svojstvu gospodin Kopp imao prisluškivane svoje telefone, s obzirom na to da je on bio odvjetnik i svi telefoni njegovog odvjetničkog društva su bili nadzirani.

Drugo, prisluškivanje i drugi oblici nadziranja telefonskih razgovora predstavlja ozbiljno miješanje u privatni život $i$ korespondenciju i mora se u skladu s tim temeljiti na "zakonu" koji je osobito precizan. Bitno je imati jasna, detaljna pravila o materiji, pogotovo jer dostupna tehnologija neprestano biva sve sofisticiranija (vidi gore navedene presude u predmetima Kruslin i Huvig, str. 23, $\S 33$, i str. 55, $\S$ 32).

S tim u svezi, Sud nipošto ne nastoji umanjiti vrijednost neke od zaštitnih mjera ugrađene u zakon, kao što je zahtjev u odgovarajućoj fazi postupka da nalog za nadziranje telefona tijela progona mora biti odobren od strane predsjednika optužnog odjela (vidjeti odjeljak 18 i 35 gore) koji je neovisan sudac, odnosno činjenicu da je podnositelj zahtjeva službeno obaviješten da su njegovi telefonski pozivi bili presretani (vidjeti odjeljak 25 gore).

73. Međutim, Sud primjećuje kontradikciju između jasnog teksta zakona koji štiti odvjetničku tajnu kada se odvjetnik nadzire kao treća strana i prakse koja se primjenjuje u predmetnom slučaju. Iako je sudska praksa uspostavila načelo, koje je uglavnom generalno prihvaćeno, da odvjetnička tajna obuhvaća isključivo odnos između odvjetnika i njegovih klijenata, zakon jasno ne propisuje kako, pod kojim uvjetima i po kome se mora činiti razlika između pitanja napose povezanih s odvjetničkim poslom prema uputama stranke u postupku i pitanja koja se odnose na aktivnosti drugačije od onih punomoćnika.

74. Iznad svega, u praksi je, najblaže rečeno, zapanjujuće da bi ovaj zadatak trebao biti dodijeljen službeniku pravnog odjela pošte, koji je član izvršne vlasti, bez nadzora od strane neovisnog suca, posebno u ovom osjetljivom području povjerljivih odnosa između odvjetnika i njegovih klijenata, koji se izravno tiče prava obrane.

75. Ukratko, švicarski zakon, bilo pisani ili nepisani, ne upućuje s dovoljno jasnoće na opseg $i$ način ostvarivanja ovlaštenja vlasti u predmetnom pitanju. Shodno tome, gospodin Kopp, kao odvjetnik, nije uživao najmanji stupanj zaštite u skladu s načelom vladavine prava u demokratskom društvu. U tome je, stoga, došlo do kršenja članka 8."

U predmetu Bykov protiv Rusije, ${ }^{30}$ iskazao je:

"76. Sud ponavlja da izraz "u skladu sa zakonom", ne samo da zahtijeva sukladnost s domaćim pravom, nego se odnosi i na kvalitetu tog prava, zahtijevajući da bude u skladu s načelom vladavine prava. U kontekstu tajnog nadzora od tijela javne vlasti, u ovom slučaju policije, domaće pravo mora osigurati zaštitu od proizvoljnog miješanja u pravo pojedinca na temelju članka 8. Štoviše, zakon mora biti dostatno jasan u svojim pojmovima kako bi pojedincima osigurao prikladnu

29 Vidjeti fusnotu 25

30 Zahtjev br. 4378/02, od 10. ožujka 2009., vidi na: http://hudoc.echr.coe.int 
uputu o okolnostima i uvjetima pod kojima su tijela javne vlasti ovlaštena pribjeći takvim tajnim mjerama (vidi Khan v. the United Kingdom, br. 35394/97, \& 26, ECHR 2000-V).

77. Sud nadalje primjećuje kako je Zakon o aktivnostima operativnih pretraga dopuštao da se „operativni eksperimenti“ provode kod istraživanja ozbiljnih zločina. Dok zakona nije definirao koje mjere takvi „eksperimenti“ uključuju, nacionalne vlasti su zauzele stav da u ruskom pravu nije postojao pravni sustav koji bi regulirao presretanje $i$ snimanje privatnih komunikacija posredstvom uređaja za radio prijenos. Vlada je isticala da postojeći propisi o nadzoru telefona nisu primjenjivi na uređaje za radio prijenos $i$ da se ne mogu proširiti na njih analogijom. Naprotiv, isticali su razliku navodeći da za uporabu uređaja za radio prijenos nije bilo potrebno sudsko odobrenje, jer ista tehnologija nije potpadala niti pod jedan postojeći propis. Prema tome, Vlada je smatrala da uporaba tehnologije koja nije naznačena u dijelu 8 Zakona o aktivnostima operativnih pretraga za nadziranje nije podložna formalnim pretpostavkama nametnutim zakonom.

78. Sud je opetovano držao da kada je u pitanju nadzor komunikacija za potrebe policijske istrage ,zakon mora biti dostatno jasan u svojim pojmovima da građanima omogući prikladnu uputu o okolnostima i uvjetima u kojima su javne vlasti ovlaštene pribjeći tajnim i potencijalno opasnom miješanju u pravo poštivanja privatnog života i korespondencije" (vidjeti Malone protiv Ujedinjenog Kraljevstva, 2. kolovoza 1984., § 67, Serija A, broj 82). Napose, da bi se poštovao zahtjev „kvalitete prava“, zakon koji određuje diskreciju mora odrediti opseg te diskrecije, iako detaljne procedure i uvjeti koji se moraju uvažavati ne moraju nužno biti inkorporirani u pravila materijalnog prava. Stupanj preciznosti „zakona" u ovom pitanju će zavisiti o konkretnom slučaju. S obzirom na to da u u praksi implementacija mjera tajnog nadzora komunikacija nije podložna nadzoru pojedinca kojeg se tiče niti javnosti uopće, bilo bi oprečno načelu vladavine prava da pravna diskrecija dodijeljena izvršnoj vlasti - ili sucu - bude izražena u okvirima neograničene moći. Posljedično, zakon mora odrediti polje svake takve diskrecije prenesene na nadležne vlasti i način provođenja iste s dostatnom jasnoćom da pojedincu zajamči prikladnu zaštitu od arbitrarnog uplitanja (vidjeti, između ostalog, Huvig protiv Francuske, 24. travnja 1990., \$\$ 29 i 32, Serija A, broj: 176B; Amann protiv Švicarske [GC], broj: 27798/95, \& 56, ECHR 2000II; i Valenzuela Contreras protiv Španjolske, 30. srpnja 1998., § 46, Izvješća o presudama i odlukama 1998-V)."

\section{NA ̌́E STAJALIŠTE}

Uzimajući u obzir sve prethodno navedeno može se zaključiti da pozitivno uređenje ZKP/97, ZKP/08 i ZKP/14 sadrži dvije temeljne vrste nezakonitih, odnosno pravno nevaljanih dokaza:

1) izravno pravno nevaljani dokazi - dokazi koji su per se nezakoniti, odnosno suprotni određenim kaznenoprocesnim, drugim zakonskim, ustavnim ili međunarodnopravnim pravilima te 
2) neizravno pravno nevaljani dokazi - dokazi koji sami po sebi nisu nezakoniti, odnosno pravno nevaljani, ali je način njihova pribavljanja suprotan određenim pravilima sadržanim u, Ustavu, međunarodnom ugovoru ili bitnim povredama ZKP-a.

Dokazne zabrane predstavljaju pravila po kojima se, s jedne strane, određena dokazna sredstva načelno isključuju od uporabe u kaznenom postupku te se neki izvori dokaza iz određenih razloga koji se svode bilo na njihovu neetičnost, striktnu zakonsku zabranjenost, odnosno njihov kriminalni karakter (primjerice, tortura, narkoanaliza i sl.), bilo na njihovu nedovoljno potvrđenu pouzdanost (primjerice, poligraf, odnosno detektor laži, hipnoza, i sl.), ne mogu rabiti za utvrđivanje činjenica u kaznenom postupku, niti se na njima može zasnivati odluka suda kojom se rješava predmet kaznenog postupka. S druge strane, isto vrijedi za dokazna sredstva i izvore dokaza koji su načelno, inače dopušteni u kaznenom postupku, ali njihovi rezultati zbog određenih propusta $u$ njihovom dobivanju odnosno $u$ korištenju tih dokaznih sredstava (ekscesna realizacija dokaznih sredstava), nemaju potreban dokazni kredibilitet i ne mogu poslužiti kao temelj za donošenje odluke o predmetu postupka.

Prva grupa dokaznih zabrana istovremeno su zabrane apsolutnog karaktera jer nikada određene metode ne mogu biti legalna dokazna sredstva pa se tako, primjerice, ni pod kojim uvjetima iskaz dobiven mučenjem ne može dokazno koristiti, a pored toga osoba koja je primijenila torturu, odnosno iznuđivala iskaz, morala bi i kazneno odgovarati.

Druga grupa zabrana je relativnoga karaktera, jer se tu radi inače o zakonom dopuštenim dokaznim sredstvima, ali se dokazi njima ostvareni ne smatraju podobnim za korištenje u kaznenom postupku te se u dokaznom smislu potpuno procesno isključuju, jer su tijekom njihova izvođenja, odnosno pribavljanja, napravljeni određeni teški propusti i pogreške, bilo da su one plod namjernog, odnosno nestručnog rada ili su, čak, proizašle iz nekih zlouporaba subjekata postupka. To bi, primjerice, bilo kada bi se osumnjičenik/optuženik u nekim od slučajeva obvezne stručne obrane, ispitao bez prisutnosti branitelja i u tom slučaju, njegov iskaz ne bi imao nikakav dokazni kredibilitet u kaznenom postupku.

U znanosti kaznenog postupovnog prava ne postoji sasvim jedinstvena terminologija o dokaznim zabranama, ali pod općim pojmom dokaznih zabrana, treba podrazumijevati sve pravne norme koje sadrže ograničenja za izvedbu određenih dokaza u kaznenom postupku, a one se mogu podijeliti na dvije temeljne grupe:

1) zabrana korištenja određenih dokaza i dokaznih sredstava;

2) zabrana vrednovanja određenih dokaza, odnosno zabrana korištenja rezultata nekih dokaznih sredstva. ${ }^{31}$

31 Berislav Pavišić et al., Kazneno postupovno pravo, Pravni fakultet Sveučilišta u Rijeci, 3. izd., Rijeka, 2010., str. 66. do 70, 274., 308. do 314. i 328. do 330. 
Primjerice mučenje kao zabranjena metoda ili korištenje nekih kemijskih sredstava kojima se djeluje na volju osobe koja se saslušava, spadaju u zabranjena dokazna sredstva te su i dokazi pribavljeni tim dokaznim sredstvima zabranjeni. Za drugu grupu dokaznih zabrana karakteristično je da se oni mogu načelno uporabiti, ali se ne mogu dokazno vrednovati, odnosno na njima se ne može zasnovati sudska odluka.

Kazneno postupovna mjera (ili procesnopravna posljedica) zbog neuvažavanja zakonskih zabrana tijekom pribavljanja i izvođenja dokaza (ili zbog dobivanja iskaza na zakonom zabranjen način) je uvijek ista: na takvom iskazu (tj. dobivenom priznanju ili izjavi) ne može se zasnivati sudbena odluka.

Ovaj tipičan nedostatak dokaza koji je pribavljen i izvođen na zakonom zabranjen način prisutan je tijekom cijelog kaznenog postupka i nije moguća naknadna konvalidacija takvog dokaza. Zbog toga bi bila učinjena apsolutno bitna povreda odredaba kaznenog postupka ako bi sud svoju odluku utemeljio na ovako pribavljenom dokazu.

Da bi neki dokaz bio nezakonit on mora biti pribavljen povredama ljudskih prava i sloboda propisanih ustavom i međunarodnim ugovorima koje je Republika Hrvatska ratificirala ili pribavljen važnim povredama procesnog zakona. Međutim, s nezakonitim dokazima izjednačeni su i dokazi koji su dobiveni na temelju nezakonitih dokaza. Do nezakonitosti u pribavljanju dokaza može se doći u bilo kojoj etapi postupka pribavljanja dokaza, tj. u bilo kojoj etapi dokazivanja. Navedene dokazne zabrane odnose se na sve vidove utvrđivanja činjenica, nezavisno o tome je li to utvrđivanje utemeljeno na iskazu ili opažanju (primjerice, o nezakonitom načinu pribavljanja dokaza govori se onda ako je očevid, koji se poduzima kada je za utvrđivanje neke važne činjenice u postupku potrebno izravno opažanje obavljen na tijelu osobe na način da teško vrijeđa njezino dostojanstvo).

Pojam nezakonitih dokaza otvara još jedno pitanje: smatra li kaznenopostupovno pravo nezakonitim svaki dokaz koji je pribavljen na nezakonit način kršenjem propisane forme prikupljanja i izvođenja dokaza. Odgovor mora biti negativan. Nezakonitim se smatraju samo oni dokazi kod prikupljanja ili izvođenja kod kojih je došlo do kršenja određenih procesnih formi koje znače zaštitu određenih temeljnih prava i sloboda građana, odnosno prava optuženog na obranu u kaznenom postupku, dakle, tzv. zaštitnih formi. Takav zaključak proizlazi iz definicije članka 10. stavak 2. ZKP/08 (ZKP/14). Drugo je pitanje je li ta zakonska definicija namjerno ili slučajno dala preuzak i neodređeni pojam nezakonitog dokaza, ostavljajući tako otvorenim neka teorijska i praktična pitanja te mogućnost izigravanja zabrane zasnivanja presude na nezakonitim dokazima. 


\section{ZAKLJUČNO}

Međunarodni pravni akti, čini se opravdano, ne sadržavaju pravila po kojima bi se neki način pribavljanja dokaza mogao smatrati nezakonitim, već je to prepušteno isključivo domaćem pravu. U tom je smislu ESLJP postupajući na temelju odredaba EKZLJP-a pristupao rješavanju tog pitanja kazuistički. Ipak je postavio jedno čvrsto pravilo prema kojemu domaće kaznenopostupovno pravo, tijekom suđenja optuženom, mora jamčiti konkretno rješenje pitanja zakonitosti dokaza pribavljenih na nezakonit način ili povredom odredaba Konvencije. Prema tome, zakoniti dokazi su oni koji su autentični, pouzdani i relevantni, a odluku o tome donosi sud.

Konkretnije, a kada je u pitanju pravna valjanost (zakonitost) dokaza tehničkih snimki s nadziranih uređaja u odnosu na treće osobe prema kojima ne postoji sudski nalog za primjenu posebnih mjera - oslanjajući se na prethodno izneseno, ali i standard (ne)zakonitosti uspostavljen pravorijecima ESLJP-a, komparativnom se analizom nameće zaključak kako je položaj hrvatskog kazneno postupovnog sustava $\mathrm{u}$ istoj materiji bitno podnormiran.

Naime, iako je VSRH u tri citirane presude zauzeo stav o mogućnosti korištenja sadržaja tehničkih snimki prema trećima, ako su se našli u ,sferi kriminalne aktivnosti“" osobe prema kojoj su mjere određene, a njihova kriminalna aktivnost koincidira bitnim obilježjima bića kaznenih djela iz kataloga inkriminacija za koje se posebne mjere mogu naložiti, odnosno u jednoj presudi bića kaznenog djela za koje je konkretna mjera naložena (što predstavlja znatno uži okvir primjene!), ostaje činjenica kako judikatura ESLJP-a od nacionalnih zakonodavstava, a ne nacionalnih sudova, zahtijeva jasno uređenje predmetne materije na način da se ne ostavljaju dvojbe ili vakumski prostori podložni tumačenjima u domeni očekivanog stupnja zaštite ljudskih prava, a između ostalih, i prava na privatnost uopće i privatnost općenja, u smislu odredbe članka 8. EKZLJPTS-a. Notorno jest da preciznije uređenje sadržaja, uvjeta $i$, što je najbitnije, dosega primjene posebnih mjera (posebnih izvida, posebnih dokaznih radnji), odredbe ZKP/97 i ZKP/08 (ZKP/14) jednostavno ne poznaju, slijedom čega se zakonodavna aktivnost $\mathrm{u}$ istom pravcu ukazuje nužnom, očekuje li se standard zaštite predviđen temeljnim nadnacionalnim aktima zaštite ljudskih prava.

Tako Stein ${ }^{32}$ zaključuje:

"Sudovi u Republici Hrvatskoj, čini se, nešto sporije recipiraju neke standarde interpretacije prava kakvi su određeni u razvijenim demokracijama zemalja Europske unije, a u ovom slučaju to se ponajprije odnosi na standarde interpretacije prava koji su izgrađeni kroz sudsku praksu Europskog suda za ljudska prava u Strasbourgu u primjeni odredaba Europske konvencije za zaštitu ljudskih prava i temeljnih sloboda usprkos činjenici da je Konvencija prema svojoj pravnoj snazi iznad hrvatskoga zakona."

32 Stein, Josip, Rezultati prisluškivanja kao nezakoniti dokaz u kaznenom postupku kroz praksu Europskog suda za ljudska prava, Novi Informator, br. 5903/10, Male stranice, Zagreb, 2. listopada 2010., str. 2. 
U stručnoj javnosti, ali i u sudskim krugovima, najčešće se zanemaruje da je Republika Hrvatska potpisivanjem Sporazuma o stabilizaciji i pridruživanju ${ }^{33}$ prihvatila i pravnu obvezu usklađivanja domaćeg prava s europskom pravnom stečevinom. ${ }^{34}$ Od 1. srpnja 2013. godine Republika Hrvatska je punopravna članica Europske unije te je obveza "da nacionalni sud, koji je u okvirima svoje nadležnosti pozvan primijeniti odredbe prava Zajednice, ima obvezu priznati puni učinak tim odredbama (europskog prava - op. aut.), uskraćujući na vlastitu inicijativu, ako je potrebno, primjenu svake suprotne odredbe nacionalnog prava, čak ako je ona donesena i kasnije (od norme prava zajednice), te nije potrebno da sud traži ili čeka prethodno stavljanje izvan snage takve odluke zakona ili na drugi ustavom propisan način. "'35

Ovdje moramo podsjetiti na odredbu članka 141. Ustava RH. ${ }^{36}$

Hrvatski suci, prvenstveno, ali to se odnosi i na druge sudionike u pravosudnim postupcima, trenutkom članstva Republike Hrvatske u Europskoj uniji postaju i domaći suci, ali i europski suci te će se od njih očekivati da u svom radu poznaju i primjenjuju pravo Europske unije na identičan način na koji to čine njihove kolege suci država koje su već članice Europske unije. Stoga je vrlo važno da se suci već sada upoznaju s europskom pravnom stečevinom, ali i sa sudskom praksom ESLJP-a.

Dakle, ono što nas sve uskoro očekuje jeste da što prije prijeđemo s tradicionalne (nacionalne) na europsku pravnu kulturu. Što prije to bolje - svima će nam biti lakše.

\section{Ne upotrebljavajmo čekić tamo gdje možemo upotrijebiti odvijač!}

33 Narodne novine, Međunarodni ugovori, br. 14/01, 1/05, 10/08, 1/10. Vidi i Rodin, Siniša, Sporazum o stabilizaciji i pridruživanju u pravnom poretku Europske zajednice i Republike Hrvatske, Zbornik Pravnog fakulteta u Zagrebu, 53. 3 - 4(2003), str. 591. do 613.

34 Vidi Glavu VI. Sporazuma o stabilizaciji i pridruživanju.

35 Odluka Europskog suda pravde u predmetu Simmenthal II, predmet 106/77, dostupno na: $\mathrm{http}: / /$ curia.europa.eu/juris/liste.jsf?language $=$ sl\&jur=C,T,F\&num $=106 / 77 \& t d=A L L \quad$ Vidi točku 24. odluke. Dakle, Sud je zauzeo stajalište da se valjanost prava Europske unije ne može ocjenjivati prema kriterijima nacionalnog prava, uključujući i kriterije temeljnih prava zajamčenih nacionalnim ustavima, već samo u kontekstu prava Europske unije kao neovisnog izvora prava.

36 "Međunarodni ugovori koji su sklopljeni i potvrđeni u skladu s Ustavom i objavljeni, a koji su na snazi, čine dio unutarnjega pravnog poretka Republike Hrvatske, a po pravnoj su snazi iznad zakona. Njihove se odredbe mogu mijenjati ili ukidati samo uz uvjete i na način koji su u njima utvrđeni, ili suglasno općim pravilima međunarodnog prava." 
Summary

\section{/NO/LEGAL EVIDENCE IN CRIMINAL PROCEEDINGS (SPECIAL REFERENCE TO MEASURES OF SECRET RECORDING OF TELEPHONE CONVERSATIONS AND THIRD IN THESE ACTIONS)}

The paper deals with the issue of unlawful evidences within terms of Croatian criminal legal system providing brief overview of the basic principles and framework as defined by applicable legal sources, i.e. national procedural law, the Constitution and the European Convention. More precisely, it aims to analyse the validity of usage of contents gathered by means of covert recording of telephone conversation against the third party or the person against those specific measures have not been ordered, within the scope of the Art. 8. of European Convention and reasonable expectations in protection of basic rights of privacy and communication. These issues have been analysed through comparison of the national judiciary and basic rights protection standard brought by ECHR, concluding that certain changes in Croatian legislation (The Criminal proceedings act) will have to take place in order to comply with the highest standards developed.

Key word: unlawful evidences, fruit of the poisonous fruit, measures secret taping, phone conversations, The Criminal proceedings act, The European Court of Human Rights, constitutional court, Supreme Court.

\section{Zusammenfassung}

\section{(IL)LEGALE BEWEISSICHERUNG IM STRAFVERFAHREN (SPEZIELLER BEZUG AUF DIE MASSNAHMEN DER GEHEIMEN AUFNAHME VON TELEFONGESPRÄCHEN UND EINES DRITTEN IN SOLCHEN HANDLUNGEN)}

Diese Arbeit befasst sich mit der Frage der rechtswidrigen Beweise in Bezug auf das kroatische Strafprozessrecht. Ein kurzer Überblick wird über die Grundlagen und Rahmenbedingungen gegeben, die anhand geltender Rechtsquellen (des nationalen Verfahrensrechts, der Verfassung der Republik Kroatien und der Europäische Konvention) definiert sind. Der Zweck dieser Arbeit ist die Analyse der Gültigkeit der Inhaltsnutzung, die durch geheime Aufnahme von Telefongesprächen gegen einen Dritten gesammelt werden, d.h. eine Person gegen die eine solche spezifische Maßnahme ursprünglich nicht angeordnet wurde, und zwar im Rahmen der 8. Europäischen Konvention und den angemessenen Erwartungen über den Grundrechtsschutz des Privatlebens und der Kommunikation. Diese Fragen werden 
anhand des Vergleichs der nationalen Justiz und des vom EGMR gebrachten Grundrechtsschutzstandards analysiert. Man gelingt zur Schlussfolgerung, dass bestimmte Änderungen in der kroatischen Gesetzgebung (der Strafprozessordnung) notwendig sind, wenn man die gesetzten Standards erreichen möchte.

Schlüsselwörter: (Il)legale Beweissicherung, Früchte des giftigen Früchte, Massnahmen der geheimen Aufnahme, Telefongesprach, Strafprozessordnung, Europäischer Gerichtshof für Menschenrechte, Verfassungsgericht, Oberste Gerichtshof der Republik Kroatien.

Riassunto

\section{PROVE (IL)LEGALI NEL PROCEDIMENTO PENALE (UNO SGUARDO PARTICOLARE ALLE MISURE DI INTERCETTAZIONI TELEFONICHE SEGRETE ED AI TERZI IN TALI OPERAZIONI)}

Il lavoro tratta delle questioni relative alle prove illegali nell'ambito del diritto processuale penale croato, illustrando brevemente i principi di base ed i fondamenti determinati dalle fonti giuridiche applicabili, ovvero dalla legislazione processuale, dalla Costituzione della Repubblica di Croazia e dalla Convenzione europea per la salvaguardia dei diritti e delle libertà fondamentali. In concreto, il senso del contributo è di analizzare la validità dell'utilizzo (utilizzabilità) dei contenuti raccolti mediante misure di intercettazioni telefoniche segrete nei confronti di soggetti terzi, ovvero persone nei confronti delle quali tali misure non erano inizialmente intraprese, e tutto ciò alla luce dell'articolo 8 della Convenzione europea ed alla luce delle giustificate aspettative di tutela del diritto fondamentale nell'ambito della vita privata e di relazione. Dette questioni sono state analizzate mediante la comparazione tra gli esiti dei giudizi nazioni e lo standard di base di tutela del diritto fondato sulle sentenze della Corte europea dei diritti dell'uomo, giungendo alla conclusione che si rende necessario intervenire sulla legislazione nazionale (Legge sul procedimento penale) ove s'intendano soddisfare i valori ivi stabiliti.

Parole chiave: prove illegali, prodotto del frutto avvelenato, misure di intercettazione segreta, conversazioni telefoniche, Legge sul procedimento penale, Corte europea dei diritto dell'uomo, Corte costituzionale, Corte suprema. 